\title{
Hakkâri Etnografik Eserlerinden Yün Eldivenler Üzerine Bir Çalıșma
}

\section{Hasan BUĞRUL*}

\begin{abstract}
ÖZ
Eldiven, ellerimizi farklı dış etkilerden korumak için giydiğimiz bir giysidir. Kullanım amacına göre deri, süet, kumaş, yün, kaşmir, naylon, keten ve pamuk gibi malzemelerden yapıldıkları görülür. Bunlar arasında yün ile örülen eldivenler daha çok kış mevsiminde ellerimizi soğuktan koruma amaçlı givilir. Yün eldivenler, yün çoraplar gibi malzeme ve bezeme açısından önemli özelliklere sahiptirler. Bu anlamda, kültürel mirasımızın önemli unsurları arasında yer alırlar. Günümüzde, yün yerine farklı malzemeden yapılan eldivenlerin kullanımının yaygınlaşması sonucu olarak diğer birçok etnografik eser gibi ortadan kaybolma riskini taşımaktadırlar. Bütün bunlara karşın bu etnografik eserlerle bağlantılı detaylı bir bilimsel çalışmaya rastlanılmaması bu alanda çalışma yapmamızı gerekli kılmıştır.

Bu çalışmada, Hakkâri ilinin farklı yörelerinde yün eldivenlerle ilgili saha çalışması yapılmıştır. Çok az sayıda yün eldivene rastlanılması bu sanat unsuru ile ilgili kaygılarımızı artırmıştır. Ancak katalog çalışmasında da görüleceği üzere, elde edilen yün eldivenler az sayıda olmakla birlikte malzeme, çeşit ve bezeme bakımından kayda değer oldukları görülür. Yün eldivenler üzerindeki motifler aynı yöreye ait yün çoraplar üzerindeki bezemelerle de karşılaştırılarak benzerlik ve farklılıklar irdelenmeye çalışılmıştır. Görüldüğü kadarıyla, bu kültür ve sanat unsuru üzerine işlenen motiflerle Hakkâri ve aynı zamanda Anadolu'nun farklı yörelerindeki yün çorap gibi diğer örgü işler üzerine işlenen motiflerle büyük benzerlik gösterirler. Ancak yün eldivenlerin parmak uçlarındaki püsküller açısından daha çok Hakkâri yöresine özgü bir süsleme özelliğini ortaya koymaktadır. Bu çalışma ile Hakkâri yöresi yün eldivenlerinin kültür ve sanatımız açısından önemine dikkat çekerek bunların tekrar canlanmasında ve gelecek kuşaklara aktarılmasında katkı sağlanması hedeflenmektedir.
\end{abstract}

Anahtar Kelimeler: Hakkâri, yün eldiven, motif, kültür, sanat

* Dr. Öğr. Üyesi, Van Yüzüncü Y1l Üniversitesi, Van Meslek Yüksekokulu, Van/Türkiye 


\section{ABSTRACT \\ A Study on the Woolen Gloves, One of the Ethnographic Assets, of Hakkari}

A glove is a garment we wear to protect our hands against different external influences. According to the purpose of use, it is seen that they are made of materials such as leather, suede, fabric, wool, cashmere, nylon, linen and cotton. Among them, woollen gloves are mostly worn in winter to protect our hands from cold. Like woollen socks, woollen gloves have important characteristics in terms of material and appearance. In this sense, they are among important elements of our cultural heritage. Today, as a result of widespread use of gloves made from different materials instead of wool, they carry the risk of disappearing like many other ethnographic works. In spite of all these facts, a detailed scientific study related to these ethnographical works has not been found; hence a study was necessary to be done in this field.

In this study, field work on woollen gloves has been done in different parts of Hakkâri province. Coming across only few pairs of woollen gloves in some villages, it arose our anxiety about this art work. However, as it can be seen in the catalogue study, even though they are few in number, the woollen gloves obtained are of considerable value in terms of material, variety and appearance. By comparing the motifs on the woollen gloves with the ornament on the woollen socks belonging to the same locality, their similarities and differences were tried to be examined. As far as we can see, the motifs on this cultural and artistic element show great similarities with the other motifs on the knitting works socks such as woollen socks of Hakkari and different regions of Anatolia. However, in terms of the tassels at the fingertips of the woollen gloves, it mainly reveals an ornamentation characteristic unique to the Hakkari region. The aim of this study is to contribute to the revitalization and transfer of the woollen gloves of Hakkari region to future generation by attracting attention to their importance in terms of our culture and art.

Keywords: Hakkâri, woollen gloves, motif, culture, art 


\section{Giriş}

Takkâri coğrafi olarak dağlik bir araziye sahiptir. Bazı yerleşim yerleri 1 deniz seviyesinden $2000 \mathrm{~m}$ kadar bir yüksekliğe sahip iken Irak sınırına yakın Çukurca ve Şemdinli yöresinde rakım 1500 metreye kadar düşmektedir. Yüksek kesimlerde kış mevsimleri soğuk olur ve buralarda yoğun kar yağışı görülür. Yaz mevsiminde yaylalarda görülen endemik bitki örtüsü insanı hayran bırakır. Buralar koyun yetiştiriciliği için çok uygundur. Geçmişteki dönemler kadar olmasa da yöre halkı kış mevsimindeki zorlu yaşam şartlarının üstesinden gelebilmek için yaylalarda yetiştirdiği koyunların sütünden, yününden, etinden ve derisinden yararlanır. Dana ve/veya teke derisinden yayık, koyun derisinden ise yağ ve peynir tulumu yapılır. Yünün elde edilmesi ve işlenme işinin bir şenliğge dönüştürüldüğü görülür. Koyunlar kırkılmadan önce yıkanmazkenkuzular bir gölde veya ırmakta yıkanır. Koyun ve kuzularkırkılacağı zaman komşu köylerden yardıma gelenler olduğu gibi bu durumu firsat bilip yakınlarını ziyarete gelenler de olur. Köylüler tarafından ziyafetler verilir. Kuzu / koyun kırkma yarışları düzenlenir. Halaylar çekilir. Günümüzde Hakkari Valiliğince “Berçelan”yaylasında kuzu kırkma şenlikleri düzenlenmektedir.

Yünün işlenmesi de benzer şekilde bir eğlenceye dönüştürülür. Yünler yıkanırken ve taranırkenkomşu kızlar ve kadınlar birbirlerine yardım ederler. $\mathrm{Bu}$ işi yaparken şarkılar söylerler ve keyifli vakit geçirirler. Yünün belirli bir kısmından döşek, yorgan ve yastık yapılır. Geri kalan kısmı ise örgü ve dokuma işleri için ayrılır.

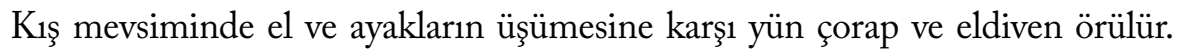
Halı dokuması az görülürken, yaygı, yatak örüsü ve daha farklı amaçlarla yapılan kilimlerin yapımı çok yaygındır. Geçmişte taşımacılık genellikle at ve katır gibi hayvanların sırtında yapılırdı. Eşyaların bu hayvanların sırtında taşınması için de çuval ve farklı ebatlardaki heybeler kullanılırdı. İnsan sırtında farklı eşya taşımında ise çanta, heybe ve "parzun" gibi dokumalar yapilır. Dokuma ve örgüde kullanılan renkli ipliklerin çoğu dokumacı ve örgücülerin bizzat kendileri tarafından farklı bitkilerden elde ederler.Bu eserlere bakıldığında malzemenin sanata nasıl dönüştürüldüğüne şahit olunur.

Günümüzde köylerdeki sosyal yaşamın hızla değiştiğini görmekteyiz. Şehir merkezindeki yaşam köylerde yaşayan insanları da büyük ölçüde etkisi altına almıştır.İ̧şen artan vakitlerini farklı uğraşlar yerine televizyon programlarını izleyerek geçirmektedirler. Böylece geleneksel yöntemlerle yapılan dokuma ve örgü işlerini yapanların sayısında da ciddi şekilde azalma vardır. Erkeklerin de benzer şekilde tarım ve hayvancılık işlerini terk ettikleri görülür. 


\section{Yün Eldivenlerin Sanat ve Toplumsal Kültürle İlişkisi}

Ellerimizi soğuktan koruma gibi bir gereksinimden ortaya çıkan "eldivenler" aynı zamanda kültür ve sanatımızın önemli bir unsuru olarak önümüze çıkarlar. Üzerlerine işlenen her bir motif ve desen farklı bir anlam ve temaya sahiptir. Bunun için de her bir örgücü eldiveni ördüğü kişiye duygu ve düşüncelerini bu motifler vasıtasıyla ulaştırma hesabını yapar. Bunun için de diğer dokuma ve örgü eserlerine işlenen motiflerde olduğu gibi yün eldivenler üzerine işlenen motif ve desenlerin anlamı ve bunun arkasındaki gizli mesaj ve hikâyeler anlaşılmadıkça gerçek değerlerini anlayamayız. Diğer sanat unsurları gibi bir el sanatı unsuru da bir somut obje olmasının ötesinde üzerlerine işlenen motif ve desenlerle farklı anlam ve temaya sahiptirler.

$\mathrm{Bu}$ bilgiler 1şığında ifade etmek gerekirse, Hakkâri yün çorapları da bu çerçevede değerlendirilmedikçe ve "kültür - sanatla" ilişkileri anlaşılmadıkça gerçek değerlerinin bilinmesi mümkün değildir. Sarıtaş (2007: 1211) el sanatlarının kültürle bağlantısına şu şekilde yer verir:

"Genel olarak, insanoğlunun duygu ve düşüncelerini maddede yoğunlaştırıp; onları sanatsal olarak ifade etmesi anlamına gelmektedir. Bugün maddi kültürün en canlı örneklerini geleneksel teknik ve aletlerin kullanılması ile ortaya çıkan ve nesilden nesile aktarılan el sanatlarımız oluşturmaktadır. Bu nedenle, el sanatları sadece üretil- dikleri toplumların kültürlerini yansıtmakla kalmazlar, aynı zamanda onları üretenlerin duygu, düşünce ve dünya görüşlerini de yansıtırlar".

Yün eldivenler "uygulamalı sanat" eserleri arasında yer alırlar. "Kültür" kavramı içerisinde yer alan "sanat" ile ilgili olarak da Bozkurt (1995: 15) şu hususlara değinir:

"Genel olarak herhangi bir etkinliğin ya da bir işin yapılmasıyla ilgili yöntemlerin, bilgilerin ve kuralların tümüne birden sanat denir. Sanatsal etkinliği; bazı düşüncelerin, amaçların, duyguların, durumların ya da olayların, deneyimlerden yararlanarak, beceri ve düş gücü kullanılarak ifade edilmesine ya da başkalarına iletilmesine yönelik yaratıcı bir insan etkinliği diye de tanımlanabilir" (Bozkurt, Nejat, 1995, s. 15).

Her bir sanatçının ortaya çıkardığı her bir eserde kendi yeteneği, düşüncesi, hayal gücü, inancı yanında içinde bulunduğu çevreye ve topluma ait değerlerin de önemli bir katkısı vardır. Bu bağlantıyı Taylor şu şekilde aktarır: "Kültür; bilgiyi, imanı, sanat ve ahlakı, örf ve adetleri, ferdin bir cemiyetin üyesi olması sebebiyle kazandığ1 alışkanlıkları ve bütün maharetleri içine alan karmaşık bir bütündür” (Erdoğan, İlhan, 1983 :113). 


\section{Materyal ve Yöntem}

Hakkâri yün eldivenleri ile ilgili çalışma beş yıl kadar bir süreyi kapsamakla birlikte en yoğun çalışma 2017- 2018 yılları yaz dönemi Haziran ve Ağustos aylarındaki 30 kadar yerleşim alanını kapsayan bir çalı̧̧madır. "Hakkâri Etnografik Eserleri” genel olarak araştırılırken yün eldivenler de bu kapsama alınmıştır. Çalışmada, eserlerin fotoğrafları çekilerek kayıt altına alındıktan sonra eserle ilgili soru-cevap yöntemiyle eserin ismi (ne olduğu), ne zaman yapıldığı, hangi malzemelerin kullanıldığı, hangi tekniklerin kullanıldığı, ne amaçla yapıldığı ve kimin tarafından yapıldığı gibi sorular yöneltilerek cevap alınmaya çalışılmıştır. Böylece, eldivenlerde kullanılan malzeme, yapım tekniği, üzerlerindeki süsleme unsurları, isimleri ve anlamları ile ilgili bilgiler elde edilmeye çalışılmıştır. Ancak eserlerin taşınır olması, bir kısmının Hakkâri'nin farklı yerlerinden ve kişilerden elde edilmiş olması vb. nedenlerden dolayı bütün eldivenlerle ilgili detaylı bilgiye ulaşılamamıştır. Hakkâri, bu ilimize bağlı ilçeler, beldeler ve köylerinde olmak üzere yaklaşık 30 yerleşim yerinde sadece 20 çift yün eldivene rastlanılmıştır. Bu rakam geçmişte neredeyse sadece bir evde rastlanan eldiven sayısı kadardır. Çoğu kişi iş eldiveni yanında bir yere gidileceği zaman özenle örülmüşs seyahat eldivenine sahipti. Evde ihtiyaç fazlası yün çorap ve eldiven de mutlaka oldurdu. Gelen özel misafirlere hediye edilirdi. Günümüzde yün çorap örgüsü kısmen devam etmekle birlikte yün eldiven örgüsü ve kullanımı artık durma noktasındadır. Bu da bir sanatın daha ortadan kaybolma riski ile karşı karşıya kaldığını gösterir acı bir durumdur.

Yün eldivenlerle ilgili yapılan literatür ve saha çalı̧̧ması sonucunda elde edilen bilgiler çerçevesinde "Hakkari yün eldivenleri” malzeme,örgü tekniği, kullanılan bezeme açısından katalog şeklinde ele alınmıştır. Bunun yanında Hakkâri yün çoraplarıyla olan birçok benzer özellikleri de dikkate alınmıştır. Hakkâri yün eldivenleri ile ilgili şu yerleşim yerlerinde saha çalışması yapılmıştır:

- Hakkâri merkez ve il merkezine bağlı Akçalı köyü,Bağışlı köyü, Oluklu köyü, Duran Kaya beldesi, Geçitli beldesi, Kamışlı köyü, Yağmurlu köyü, Yeni Yol köyü, Doğanyurt köyü, Boybeyi köyü, Çanaklı köyü,

- Çukurca merkez ve ilçe merkezine bağl1 Gündeş köyü, Üzümlü köyü, Çığlı köyü, Narlı köyü, Geçimli köyü,

- Yüksekova merkez ve bu ilçe merkezine bağlı Büyük Çiftlik beldesi, Dilekli köyü, Karataş köyü, Yeşiltaş köyü,

- Şemdinli merkez ve ilçe merkezine bağl1 Derecik beldesi, Nehri köyü, Korgan ve Aşağı Korgan köyüdür. 


\section{Yün Eldivenin Tarihçesi}

Yün eldivenler dayanıklı malzemeden yapılmadıkları için ilk ne zaman ortaya çıktıklarını tam olarak ortaya koymak mümkün değildir. Ancak yün çoraplarda kullanılan malzeme, yapım tekniği, kullanım amaçlarının "eldivenlerle" büyük benzerlik taşımasıyla bu iki giyim eşyasının yakın dönemler içerisinde ortaya çıkmış olmaları muhtemeldir. $\mathrm{Bu}$ anlamda yün çorapların tarihçesini görmekte yarar vardır. Ayten Atay’a (1987: 33) göre en erken Türk yün çorapları örnekleri Hunlara ait kurganlardaki buluntular arasında rastlanan çoraplardır. Tahmini olarak MS II. ve III. yüzyıllara tarihlendirilen çorapların konç kısmında koçboynuzu motifi işlenmiştir.

\section{Eldivenlerin Anlam ve Önemi}

"Ellerimiz", diğer fonksiyonların yanında yeteneklerimizi ortaya koymamızı sağlarlar. Bugün somut olarak ortaya çıkarılan bütün işlerde ellerimizin payı vardır. "El motiff" birçok farklı toplumun kültür ve sanatında yer aldığı gibi bizim kültür ve sanatımızda da kendisine geniş yer bulmuştur. (Akpınarlı vd. 2016: 964) el ve el motifi hususunda şunlara vurgu yaparlar:

"El, önemi itibarıyla farklı toplumların kültür ve sanatında da önemli bir yer edinmiştir. Türk-İslam sanatında "el motifi” beş vakit namazın, İslam'ın beş şartı, Peygamberimiz Hz. Muhammed (S.A.V.) ve ailesinin vb. birçok hususun sembolü olarak görülür”.

Farklı işlevleri olan elimizle ilgili olarak Ethel J. Alpenfels, D.Sc (1955) şu hususlara vurgu yapar:

"Yalnız insan ele sahiptir. Onu bir araç olarak, bir sembol olarak ve bir silah olarak kullanır. Efsane, folklor, batıl inanç ve mitoloji literatürünün bütünü insan elinin etrafinda oluşturuldu.Bir performans organı olarak körler için göz, dilsizler için konuşma görevini görür ve selamlama, yalvarma ve kınamanın sembolü haline gelmiştir.El, bilinen her toplumun yaratıcı yaşamında bir role sahiptir".

"El”, Türk-İslam olmak üzere birçok kültür ve sanatta yer alır. Sosyal yaşamımızda yakınlaşma, samimiyet, sevgi, bağll1ık ve barış gibi önemli kavramların sembolü olarak da görülür. Elimize giydiğimiz eldiven de bir şekilde elimizi temsil eder ve eldiven motifi yukarıda sıralanan bütün anlamları sembolize eder. Onun için de birine "el" motifli bir eseri veya bir çift eldiveni hediye ettiğimizde, ona olan; 
- İçten bağllı̆̆ımızı, sadakatimizi,

- Sevgimizi, samimiyetimizi,

- Aradaki kırgınlığı sona erdirme isteğimizi, barışçıl niyetimizi,

- Onurlandırma isteğimizi sunmuş oluruz.

Eldivenler insanın elini soğuktan koruma işlevi ile ortaya çıkmakla birlikte bugün yaşantımızın birçok alanında vazgeçilemez bir unsur olarak kendisine yer bulmuştur. Özen (2016:IV) günümüzdeki eldiven çeşitlerini ve işlevlerini şu şekilde sıralar:

- Mekanik risklere karşı koruyucu eldivenler,

- Kimyasal maddeler ve mikroorganizmalara karşı koruyucu eldivenler,

- Isıl risklere (1sı ve/veya ateş) karşı koruma sağlayan eldivenler,

- Soğuğa karşı koruyucu eldivenler,

- Gerilim altında çalışma için yalıtkan eldivenler,

- Biçak kesiklerine ve batmalarına karşı koruyucu eldivenler,

- İyonlaştırıcı radyasyon ve radyoaktif kirlenmeye karşı koruma sağlayan eldivenler ve kaynakçı eldivenleri.

\section{Malzeme}

Günümüzde çok farklı amaçlarla eldiven üretilmektedir ve her amaca uygun da malzeme kullanılmaktadır. Kullanılan malzemeler arasında deri, süet, kumaş, yün, kaşmir, naylon, keten ve pamuk gibi unsurları saymak mümkündür. Hakkâri yöresinde teşi ile bükülen yün iplik en yaygin iplik çeşidi iken keçilerin alt ince gömleğini oluşturan liflerden yapılan eldivenler de çok rağbet görür. Tiftik liften yapılmış gibi bir özelliğe olduklarından yörede "tiftik eldiven" olarak adlandırılmaktadırlar. Hakkâri yöresinde eldiven örgüsünde 5-3 veya 2 şiş ile eldivenler örülebilmektedir. Tı̆̆ ile eldiven örgüsü çok nadir görülür. Kullanılan iplik eldivenin kalitesinde önemli bir yere sahiptir. Dört kat yün iplik çok nadir görülür. Günümüzde örülen kaliteli olan eldivenlerde elde bükülmüş üç kat yün ipliktir.

\section{Teknik}

Hakkâri yöresinde eldivenler genellikle beş şiş kullanılarak örülür. Örme işlemine bilek kısmından başlanır. Örülecek eldivenin büyüklüğü göz önünde bulundurularak ilmek hesaplanır. Eldivenin parmak kısmında genellikle 3 şiş kullanılır ve serçe parmağından başlanır. Kullanım amacına göre ve kullanacak kişinin yaşına göre sade, düz, renkli, desenli ve/veya püsküllü yapılır. 


\section{Yün Eldiven Çeşitleri}

Yün çorap gibi eldiven çeşitlerini de belirli gruplar altında sınıflandırmak zordur. Çünkü kullanılan malzemenin çeşitliliği, örgü tekniği, bezeme, kullanım amacı ve kimler tarafindan kullanıldığı hususlarının her birinin eldivenlerin ortaya çıkmasında etkileri vardır. $\mathrm{Bu}$ hususlar göz önünde bulundurulduğunda Hakkâri yöresi geleneksel yün eldivenlerini şu şekilde sınıflandırmak mümkündür:

\section{Malzemeye Göre Hakkâri'de Görülen Eldivenler}

- Yün eldivenler

- Keçi alt ince gömleini olu_turan liflerden yap1lanlar.

\section{Bezemeye Göre Hakkâri Yün Eldivenleri}

- Örgü desenli eldiven

- Tamamı bezemeli eldiven

- Motifli ve örgü desenli eldivenler

- Motifli, örgü desenli ve parmak uçları püsküllü olan eldivenler.

\section{Kullanım Amacına Göre Hakkâri Yün Eldivenleri}

- Rençber / iş yün eldiveni

- Seyahat yün eldiveni.

\section{Biçimsel Özelliklerine Göre Hakkâri Yün Eldivenleri}

- Tek parmaklı yün eldiven

- Üç parmaklı yün eldiven

- Beş parmaklı yün eldiven

\section{Kullanan Kişiye Göre Hakkâri Yün Eldivenleri}

- Çocuk yün eldiveni

- Erkek yün eldiveni

6. Süs Eldivenler: Evin bir köşesinde, araba ön camlarında, bayanların el çantalarında vb. birçok yer ve eşya üzerinde bir aksesuar olarak görülürler.

7. Namaz bilekliği: Kadınlar, elbise kolları kısa olması durumunda namaza durmadan önce giyerler. Böylece el bileği ile elbise kolu arasındaki açıklık bunların vasıtasıyla kapatılmış olunur. 


\section{KATALOG}

No: 01

Eldiven türü: Erkek eldiveni

Malzeme: Kaşmir. Keçi alt ince gömleğinden elde edilen lif

Renk: Kahverengi ve beyaz renkler kullanılmıştır.

Kullanılan motif: Çengel ve saç örgüsü örgü deseni

\section{Ören kişi: Anber BUĞRUL, Örüldüğü tarih: 1954}

Tanım: Kahverengi ve beyaz kaşmir iplikle örülen eldivenin bilek kısmında lastik örgü tekniği kullanılmıştır ve "V" şeklindeki bir geometrik şekil içerisine şeritler halinde saç örgüsü örgü desen yerleştirilmiştir. Parmak kısmına bakan tarafinda çengel motifi kullanılmıştır. Başparmak başlangıcı hizasında dört parmakta şerit şeklinde çengel motifi tekrarlanmıştır. Parmak uçlarında aynı bezeme tekrarlanmıştır. Eldiven parmakları dikişsiz örme tekniği ile örülmüştür.

Özellikleri: Keçi kılları arasında kaşmir (yün vari) bir tabaka vardır. Bu tabaka kışın keçileri soğuktan korur. Soğuk havaya karşı koruyucu özelliği taşıyan bu tabaka eldiven ve çorap için de ideal bir malzemedir. Keçi besleyen aileler onların soğuk havaya karşı hassasiyetlerini de gözeterek kıllarını taramak suretiyle her birinden az miktarda alırlar. Elde edilen yün vari malzeme yıkanmaz. Ancak iplik haline getirebilmek için önce yün tarak ile taranır ve daha sonra da teşi ile bükülerek iplik haline getirilir. Bu iplikle kışlık çorabın yanı sıra eldiven örgüsünde de kullanılır. Bu malzemeden örülen çorap ve eldivenler tamamlandıktan sonra yıkanabilir. Bu tür çorap ve eldivenlere çok nadir rastlanır.

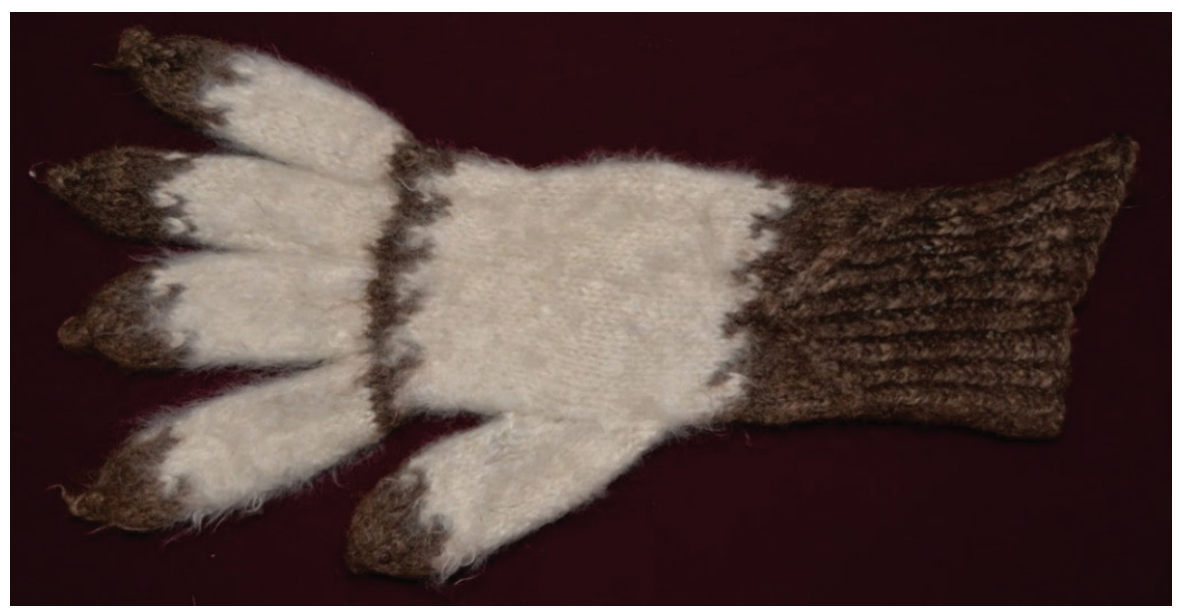

Fotoğraf 1. Keçi kılları arasında yün vari bir tabakadan elde edilen iplikle (kaşmir) örülen eldiven. 


\section{Örnek No: 02}

Eldiven türü: Erkek yün eldiveni

Malzeme: Teşi ile elde bükülmüş üçem (üç katlı) yün iplik.

Renk: Beyaz, siyah, kırmızı ve mavi, Kullanılan motif: Göz, petek

Tanım: Beyaz, siyah, mavi ve kırmızı yün iplik malzeme ile örülen eldiveninbilek kısmına lastik örgü tekniği uygulanmıştır. Petek desenin hakim olduğu yün eldivenin orta kısmında "göz" motifi kullanılmıştır. Başparmak ucu hizasında ve bilekte kısmındaki lastik örgünün bitiminde eli belinde motifi şeklinde birer bezemeye yer verilmiştir. Eldiven parmaklarında dikişsiz örgü tekniği uygulanmıştır ve örgüde beş şiş kullanılmıştır. Göz motifinde kullanılan mavi ve kırmızı renklerle bu eldivenin genç yaştaki biri için örüldüğü anlaşılmaktadır.

Özellikleri: Elleri soğuktan koruma amaçlı yapılan bir tür eldivendir. Eldiven üzerinde görülen süsleme unsurlarından nazar motifini ve kullanılan renkleri değerlendirdiğimizde bu eldivenlerin genç yaştaki bir erkek tarafindan kullanıldığına işaret sayabiliriz.

Kullanılan motifin anlamı: Bu yün eldiven üzerinde "çengel, petek ve eli belinde desen" ile göz motifi bezeme unsuru olarak kullanılmıştır. Nazara karşı kullanılan motiflerden biri olan ve bu yün eldivende ana bezeme unsuru olan "göz motifi" ile ilgili olarak Güran Erbek (1987:35) şu huşulara yer verir: Kötü bir bakışın kaynağı insan gözüdür. Onun neden olabileceği zararların yine en iyi şekilde insan gözüyle tekrar önlenebileceğine inanılır. Gözün, dokuma işlerinde dört bölüme ayrılmış eşkenar dörtgen (baklava desen) şeklinde kullanımı oldukça yaygındır. Üçgen şekil gözün stilize biçimidir. Bazı göz motifleri kare ve dikdörtgen biçime sahiptirler.

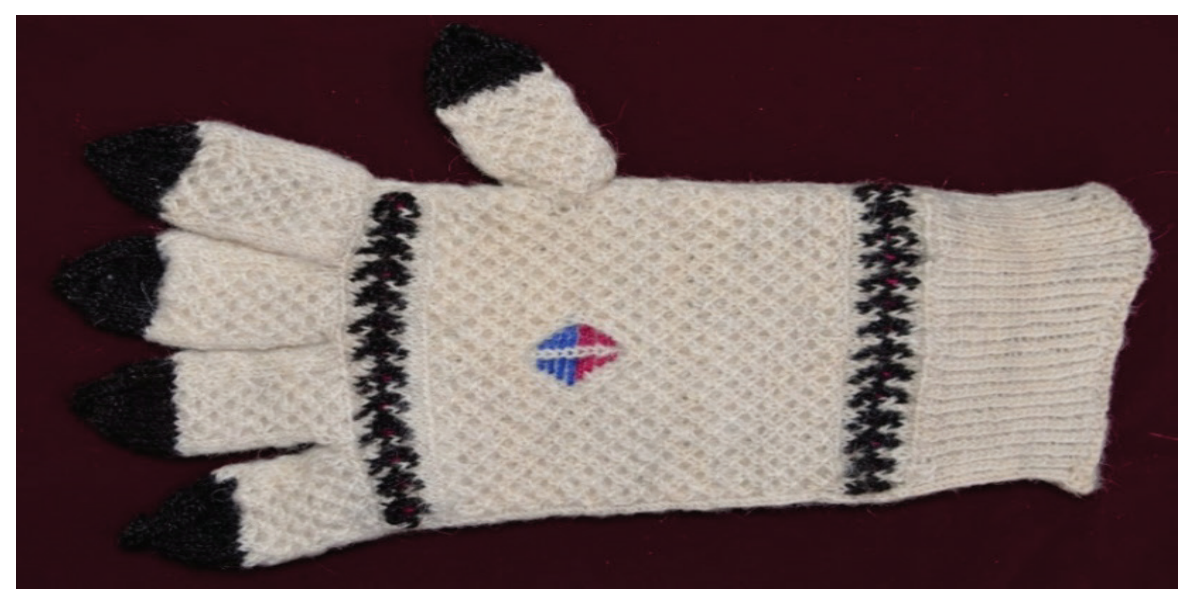

Fotoğraf 2. Hakkâri yöresi göz (nazar) motifli yün eldiven 


\section{Örnek No: 03}

Eldiven türü: Erkek yün eldiveni

Malzeme: Teşi ile elde bükülmüş üçem (üç katlı) yün iplik.

Renk: Beyaz, siyah ve kırmızı

Kullanılan motif: Eli belinde, çengel, baklava motif ve üçgen biçiminde geometrik şekiller

Tanım: Yün eldivende siyah, beyaz ve kırmızı olmak üzere üç renkte yün iplik kullanılmıştır.Bilek kısmına lastik örgü tekniği uygulanmıştır. Bilekteki lastik örgünün ortasına sıralı ve ortasına kırmızı bir şerit geçecek şekilde baklava desen işlenmiştir. Lastiğin bitiminde de zikzak şeklinde üçgen geometrik bir bezemeye yer verilmiştir. Bilekteki lastik örgü ile parmak başlangıcı hizasına kadar gelen kısım üzerinde üç adet eli belinde motifi işlenirken iki kenarında çengel motifi görülmektedir. Parmak uçlarına doğru çubuk şeklinde çizgiler yer almaktadır. Parmak uçlarında da aynı iplikten yapılmış püsküller eklenmiştir.

Özellikleri: Elleri soğuktan koruma amaçlı yapılan bir tür eldiven çeşididir. Eldivendeki püsküller, kullanilan yün ipliklerin renkleri ve bezeme özelliklerinden de anlaşılacağ 1 üzere bu eldivenlerin "genç” yaştaki bir erkek tarafindan kullanıldığı düşünülmektedir.

Kullanılan motifin anlamı: Ana motif olarak eli belinde motifi kullanılmıştır. Bu motifin anlamı ile ilgili olarak Güran Erbek (1987: 7) şunları ifade eder: Temel tasarım stilize edilmiş kadın olmasına rağmen, bu desen Anadolu'da gelin kız, çocuklu kız, aman kız, karadöşeme, seleser, kahküllü kız, çengel, sarmal, çakmaklı, eğer kaşı, turna katarı gibi çeşitli isimlerle bilinir. Annelik ve doğurganlı̆̆ın simgesidir.

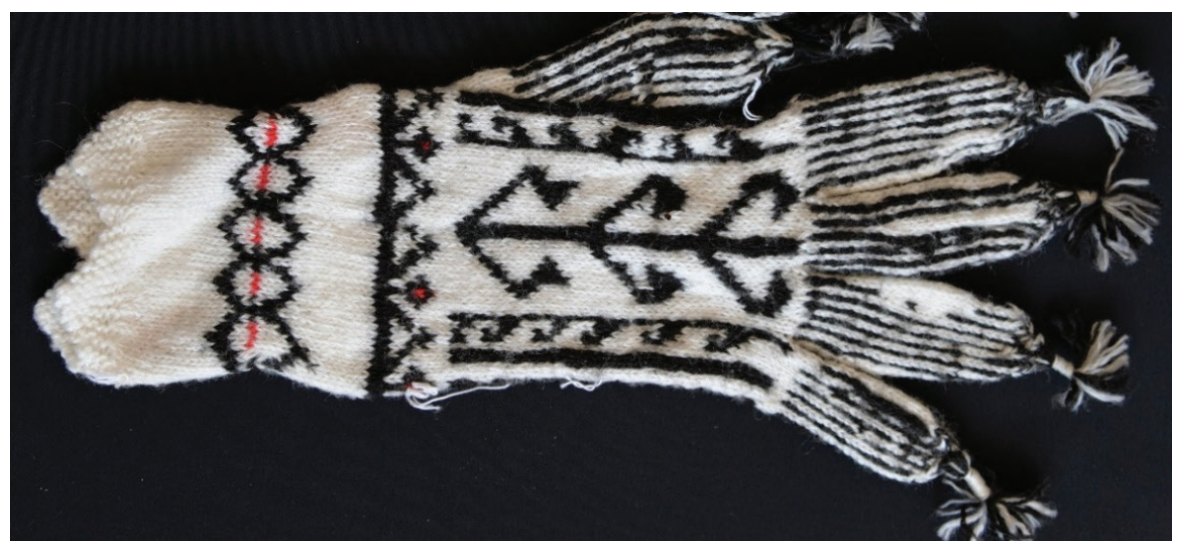

Fotoğraf 3. Bilek kısmı örgü lastikli, eli belinde motifli, dikişsiz parmak örgülü 


\section{Örnek No: 04}

Eldiven türü: Kadın yün eldiveni

Malzeme: Orlon iplik

Renk: Kırmızı ve siyah

Kullanılan motif: Koçbaşı, çengel ve hayat ağacı

Tanım: Kırmızı ve siyah renkli iplikler kullanılmıştır. Tamamı renkli ve desenli oluşundan bu yün eldivenin bir genç kadın tarafından kullanıldığını gösterir. Başparmak hizasına kadar alt alta koçbaşı motifi ve çengel motifi kullanılmıştır. Parmaklarda hayat ağacına benzer bir bezemeye yer verilirken kenarlarına da yıldız şeklinde noktalar yerleştirilmiştir.

Özellikleri: Kış mevsiminde elleri soğuk havaya karşı korumak amaçlı giyilir. Canlı renkleriyle genç kadınlar için veya kızlar için örülen bir tür eldivendir. Bu eldivenin bilek kısmına lastik örgü tekniği uygulanmamıştır.

Kullanılan motifin anlamı: Koçbaşı motifi, Hakkâri yöresindeki dokuma ve örgü işlerinde çok rastlanılan bir bezeme çeşididir. Koç ve koç motifi ile ilgili bilgiler arasında şu hususlar yer alır: "Liderliğin sürekli olarak koçla irtibatlandırılması hükümdar imajına uymaktadır. Eskiden hayvan yetiştiricileri koçun liderlik, koruyuculuk, hâkimiyet ve bereket özelliklerine değer veriyorlardı"(Çevirinin yapıldığ 1 kaynak: Dora 2011: 4-13). Çoruhlu'ya (1988: 34) göre de, "ancak koçun en belirgin sembolik anlamı onun koruyuculuk vasfidır. Koçun koruyuculuk, gözetleme ve gücün sembolü olma anlamı şimdiye kadar hiç değişmemiştir”.

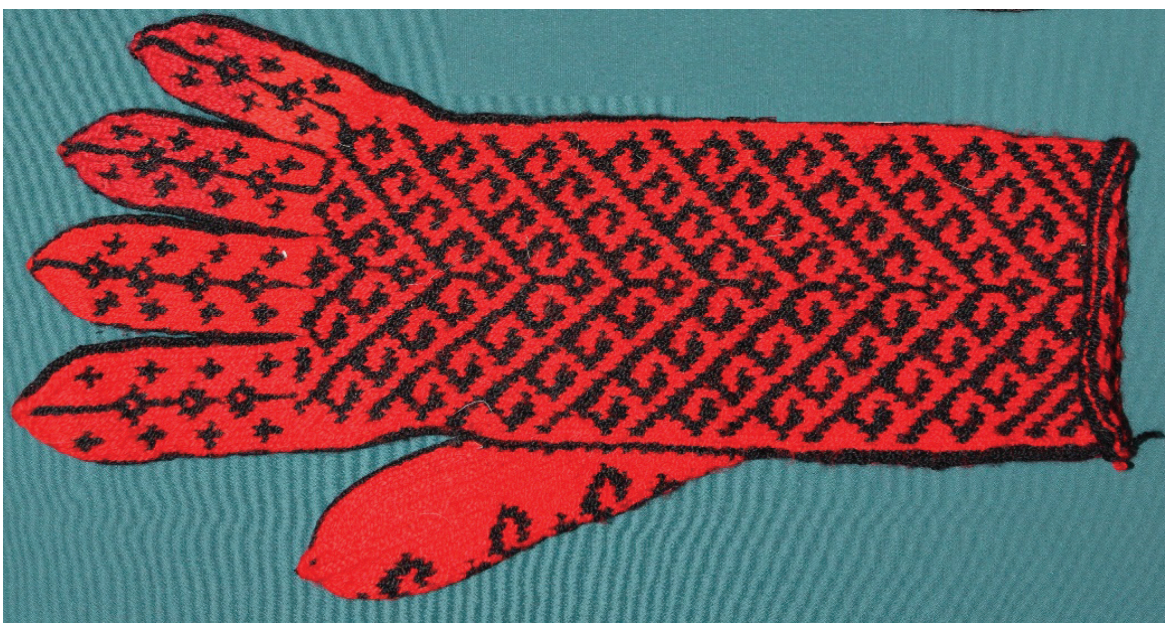

Fotoğraf 4. Tamamı renkli, desenli - koçbaşı ve çengel motifli yün eldiven 


\section{Örnek No: 05}

Eldiven türü: Erkek yün eldiveni

Malzeme: Teşi ile elde bükülmüş üçem (üç katlı) yün iplik.

Renk: Beyaz ve siyah

Kullanılan motif: Hayat ağacı ve çengel / çakmak

Ören kişi ve örüldüğü tarih: : Edibe Yılmaz, 2002.

Tanım: Tamamı desenli erkek yün eldiveninde bilek kısmına örgü lastik tekniği uygulanmıştır. Bilek kısmındaki örgü lastik kısmından başlanarak parmak uçlarına kadar hayat ağacı motifi, çengel motifi ve çubuk şeklinde düz çizgiler tekrarlanmıştır.

Özellikleri: Kış mevsiminde seyahat esnasında kullanılan bir tür eldivendir.

Kullanılan motifin anlamı: Bu yün eldivende hayat ağacı motifi ön plana çıkmaktadır. Çengel ve çakmak motifleri bordür işlevindedirler. Çengel, iplik ile teşi denilen alet arasındaki bağlantıyı sağlar. Bu anlamda, "çengel" motifini de insanlar arasındaki yakın bağ ve ilişkilere işaret sayabiliriz. Hayat ağacı motifiile bağlantılı hususlar arasında şunlara rastlanır: "Ağaç, tek tanrıya inanılan bütün dinler için ortak temadır. Ölümsüzlük getirdiğine inanılan meyvesi Hz. Adem ve Havva için yasaktır. Ama ağacı bekleyen iblis Havva'nın o meyveyi yemesi için ikna etti. İnsanoğlu yeminini tutmada başarısız oldu, hayat ağacı ile sembolize edilen bütün umutlarını ölümden sonraki hayata bıraktı. Farklı kültürler selvi, hurma, palmiye, nar, incir, zeytin, üzüm, kayın ve meşe gibi farklı bitkiler kullanırlar. Anadolu'daki belirgin şekil selvi ağacıdır. Hayat ağacının üzerindeki kuşlar yaygın olarak kullanılan bir temadır” (Çevirinin yapıldığı kaynak: Taşkıran: 2006).

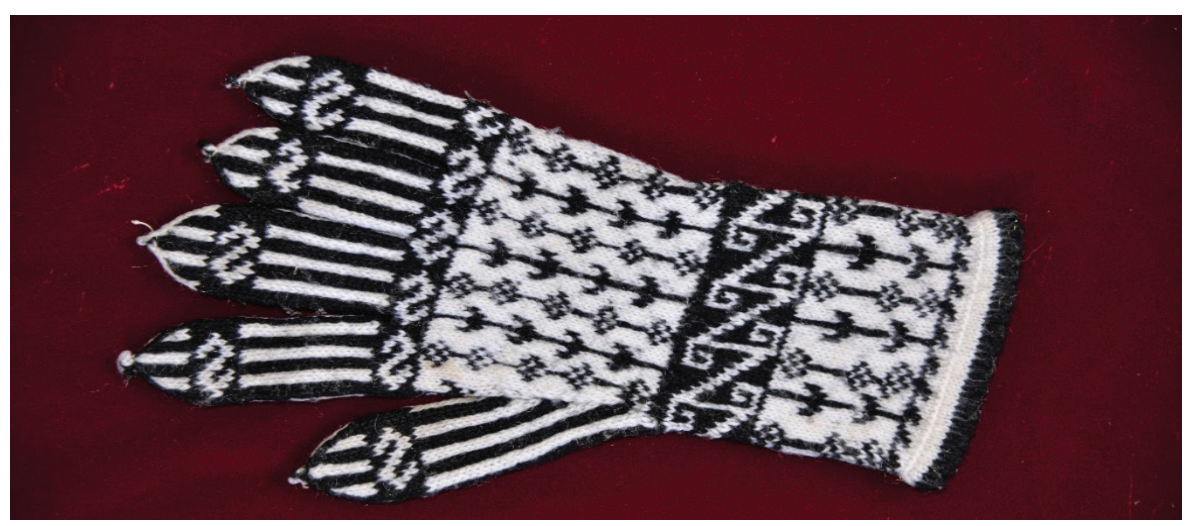

Fotoğraf 5. Tamamı desenli, çengel ve hayat ağacı motifli yün eldiven 


\section{Örnek No: 06}

Eldiven türü: Erkek yün eldiveni

Malzeme: Teşi kullanılarak elde bükülmüş yün iplik; Renk: Beyaz

Ören kişi ve örüldüğ̈̈ tarih: Saliha Canatak, 2005.

Kullanılan motif: Baklava (eşkenar dörtgen)

Tanım: Beyaz üçem yün iplikle örülmüş beş parmaklı yün eldivendir. Bilek kısmına örgü lastik tekniği uygulanmıştır. Eldivenin iki tarafına avuç içini ve üst tarafını kaplayacak büyüklükte birer adet baklava (eşkenar dörtgen) şeklinde geometrik bir bezemeye yer verilmiştir. Baklava şeklindeki bezemenin her iki tarafını sınırlayan şeritler yer alır.

Özellikleri: İki ucu sivri beş şiş bu eldiven örgüsünde kullanılırken, parmak kısımlarına dikişsiz örgü tekniği uygulanmıştır. Kış mevsiminde elleri soğuktan koruma amaçlı kullanılan bir tür eldivendir. Genç yaştakilerin giyebileceği bir tür eldiven olarak görünmekle birlikte püskülsüz olması ve renkli yün ipliğe yer verilmemesiyle daha çok yetişkinlerin tercih edebileceği türdedir.

Motifin anlamı: Hakkâri dokuma ve örgü işlerinde İslam öncesi inanç ve kültürlerin etkisinden devam eden birçok motife rastlanır. Bunlar arasında nazar motifi de yer alır. İnsanları nazar ve kötülüklere karşı koruyacağı düşüncesine dayanan pıtrak motifi, göz motifi, muska motifi, el motifi, yılan motifi, ejder motifi ve akrep motifi yanında Mühr-i Süleyman ve baklava desen de yer alır.

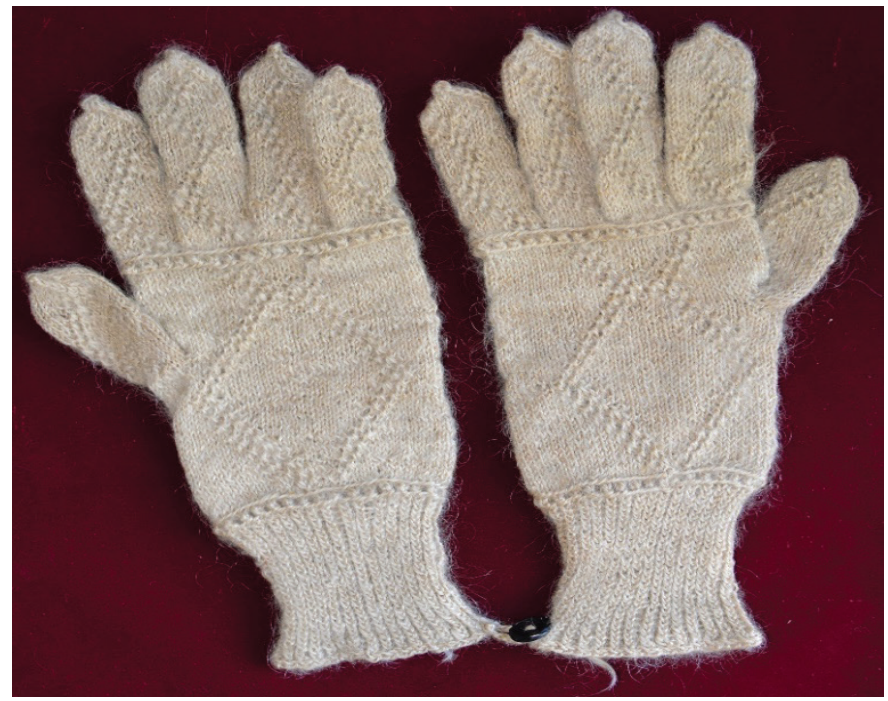

Fotoğraf 6. Örgü baklava desene sahip yün eldivenler. Geçitli köyü, Hakkâri. 


\section{Örnek No: 07}

Eldiven türü: Kışl1k iş yün eldiveni

Malzeme: Teşi ile elde bükülmüş iki katlı yün iplik.

Renk: Beyaz, siyah, mavi ve kırmızı

Kullanılan motif: Petek örgü desen, eli belinde ve nazar motifi

Tanım: İki tarafı sivri beş şişle örülmüştür. Dikişsiz örgü tekniğinin uygulandığı parmaklarda farklı renklerde uç kısımlarına püsküller görülür. Bilek kısmında da örgü lastik tekniği uygulanmı̧tır. Bilek kısmındaki örgü lastik eli belinde motifi ile sonlandırılmıştır. Daha sonra eldiven örgüsüne petek desenle devam edilmiştir ve başparmak hizasından yine eli belinde motifi ile sınırlandırılmıştır. Eldivenin üst kısmının ortasında mavi ve kırmızı renklerden oluşan bir nazar motifi kullanılmıştır. Canlı renkler ve parmak uçlarındaki püsküller genç bir erkeğin bu eldivenleri kullandığını göstermektedir.

Özellikleri: Kış mevsiminde elleri soğuktan koruma amaçlı kullanılan bir eldivendir. Üzerindeki kırmızı ve mavi renklerden oluşan nazar motifi ile bu eldivenin genç yaştaki biri için örüldüğü anlaşılmaktadır.

Motifin anlamı: Bezeme olarak petek desen, eli belinde motifi ve nazar motifinin kullanıldığ 1 bu yün eldivende "nazar" motifi ve nazara karş1 kullanılan bazı takılarla ilgili Çelik (1974:168) şunları aktarır: "Nazardan Allah’a sığınınız. Çünkü göz (değmesi), nazar gerçektir” şeklindeki hadisi, nazar inancının dini yönden de dayanağı olmuştur. Ancak Hz. Muhammed'in (S.A.V.) nazarın varlığını kabul etmesine rağmen, nazardan korunmak için uygulanacak çeşitli pratiklerin ve takılacak eşyaların günah olduğunu ve dinde yer almadığını söylemesi, nazardan korunmak için kullanılan uygulamaların ve yanışların ortadan kalkmasını sağlayamamıştır.

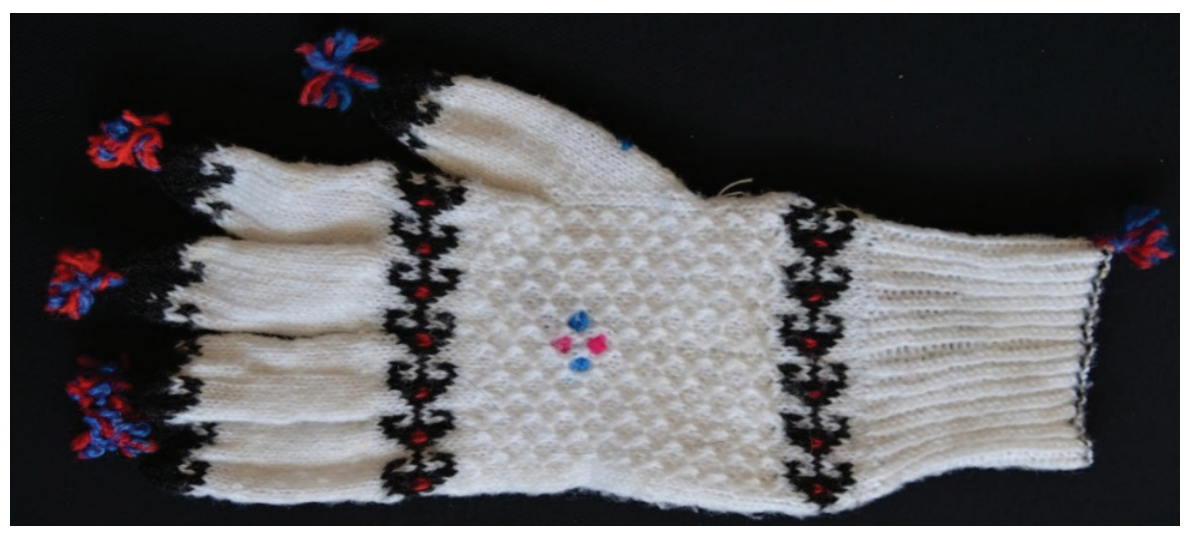

Fotoğraf 7. Petek ve eli belinde desenli, nazar motifli, püsküllü yün eldiven 


\section{Örnek No: 08}

Eldiven türü: Beş parmaklı erkek yün eldiveni

Malzeme: Teşi ile elde bükülmüş iki katlı yün iplik.

Renk: Beyaz, siyah ve kırmızı

Kullanilan motif: Pitrak ve petek

Ören kişi ve örüldüğ̈̈ tarih: Berivan Özdemir - 1995

Tanım: Eldivenin bilek kısmına "örgülü lastik" ve parmaklara "dikişsiz örgü” tekniği uygulanmıştır. Örgü lastiğin ortasına siyah renkle bir kuşağa yer verilmiştir ve örgü lastik kısmı sıralı "çengel" deseni ile sınırlandırılmıştır. Eldivenin örgü lastik kısmından sonra eldiven örgüsüne petek desenle devam edilmiştir ve orta kısmında baklava (eşkenar dörtgen) şeklindeki geometrik bir şekil içerisinde bir adet pıtrak motifi kullanılmıştır. Başparmak hizasında çengel deseni sıralı olarak kullanılmıştır. Eldivenin parmak uçları siyah ve kırmızı renkteki iplikle örgü tamamlanmıştır. Bu iki renkli yün iplik eldiven parmak uçlarındaki püskülün yapılmasında da kullanılmıştır. Bilek kısmının dış kenarında bir adet "birit” görülmektedir. Diğer eldivenin bilek kısmının örgü lastiğinin dış kısmına bir adet düğme dikilmiştir. Bu şekilde eldivenler kaldırıldığında iliklenerek bir arada tutulması sağlanmaktadır.

Özellikleri: Beş parmaklı yün eldivendir. Malzeme olarak iki ucu sivri beş şişle ve iki katlı yün iplikle örülmüştür. Canlı renkleriyle ve parmak uçlarındaki püskülleriyle genç yaştakilerin kış mevsiminde seyahate çıktıklarında yanlarına aldıkları bir tür eldivendir.

Kullanılan motifin anlamı: "Pıtrak" motifi, insanları nazar ve kötülüklere karşı koruyacağı düşüncesiyle farklı dokuma ve örgü işlerinde kullanılmaktadır.

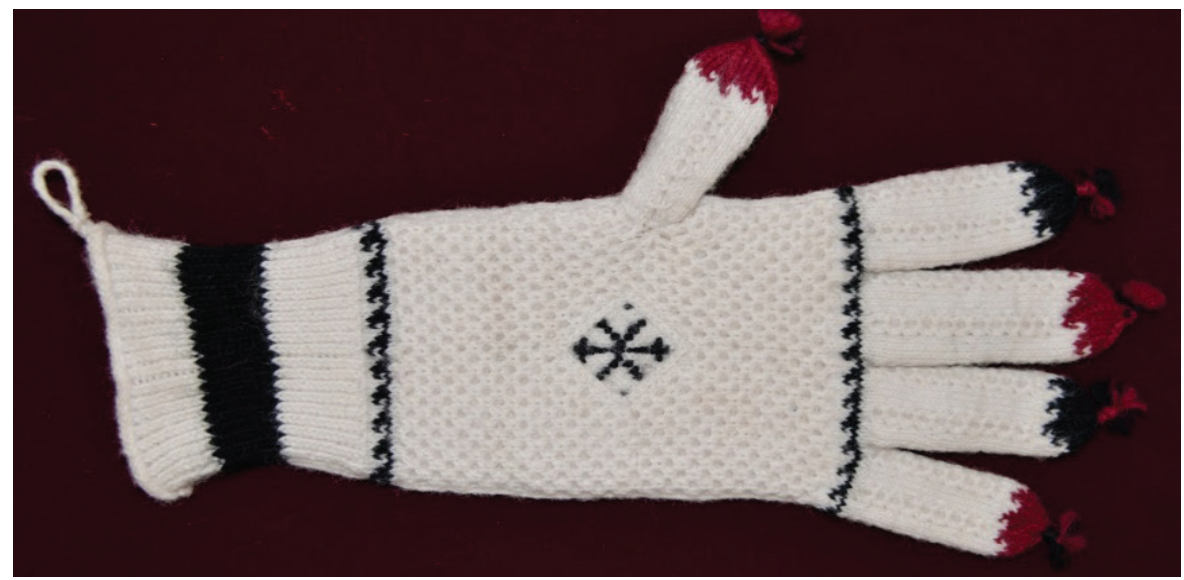

Fotoğraf 8. Hakkâri yöresi pıtrak motifli, parmak uçları püsküllü yün eldiven 


\section{Örnek No: 09}

Eldiven türü: Çocuk yün eldiveni

Malzeme: Teşi ile elde bükülmüş üçem (üç katlı) yün iplik.

Renk: Beyaz, siyah ve kırmızı; Kullanılan motif: Yıldız

Tanım: Yün eldiven beş parmaklıdır. Bilek kısmındaki örgü lastikte ikisi siyah ve biri beyaz olmak üzere üç kuşak kullanılmıştır.Bilek kısmındaki örgü lastiğin bitiminden başparmak hizasına kadar baklava bordür içerisine yerleştirilen yıldız motifleri görülmektedir.

Özellikleri: Parmakları dikişsiz örgü tekniğiyle örülmüştür. Yün eldivenin bilek kısmında örgü lastik tekniği uygulanmıştır.

Kullanılan motifin anlamı: $\mathrm{Bu}$ çocuk eldiveninde yıldı motiflerinin ana bezeme unsuru olarak kullanıldığ1 görülür. Yıldız motifinin birçok anlamı arasında şu hususlara yer verilir: "Yıldızın şekli gökyüzü ve yeryüzü arasındaki ilişkiyi açıklamak için Müslüman sanatçılar tarafından kullanılan en iyi desen olarak kabul edilirdi. Bunun bu şekilde kabul edilmesi iki üçgen şeklinin birleştirilmiş olmasıdır; kâinatı simgeleyen şekli oluşturmak için, yukarıyı gösteren üçgen gökyüzünü ve aşağıyı gösteren üçgen yeryüzünü temsil eder. Bu tür yıldız motifler kötülükleri bertaraf etmek için Fatimiler tarafindan kullanılırdı. Fatimiler dönemine ait bir kutu Mısır'da bulunmuştu; karmaşık bir deseni vardı ve ahşap kaide üzerinde birçok küçük fildişi parçaları kullanılarak kakma yapılmıştı. Altı köşeli yıldız şekli tasarımın merkezine yerleştirilmişti ve şansızlı̆̆ı önlediğine inanılan Mühr-ü 'Süleyman'ı temsil etmektedir”. (Çevirinin yapıldığı kaynak: Al-Zadjali, Z.2015:404-408).

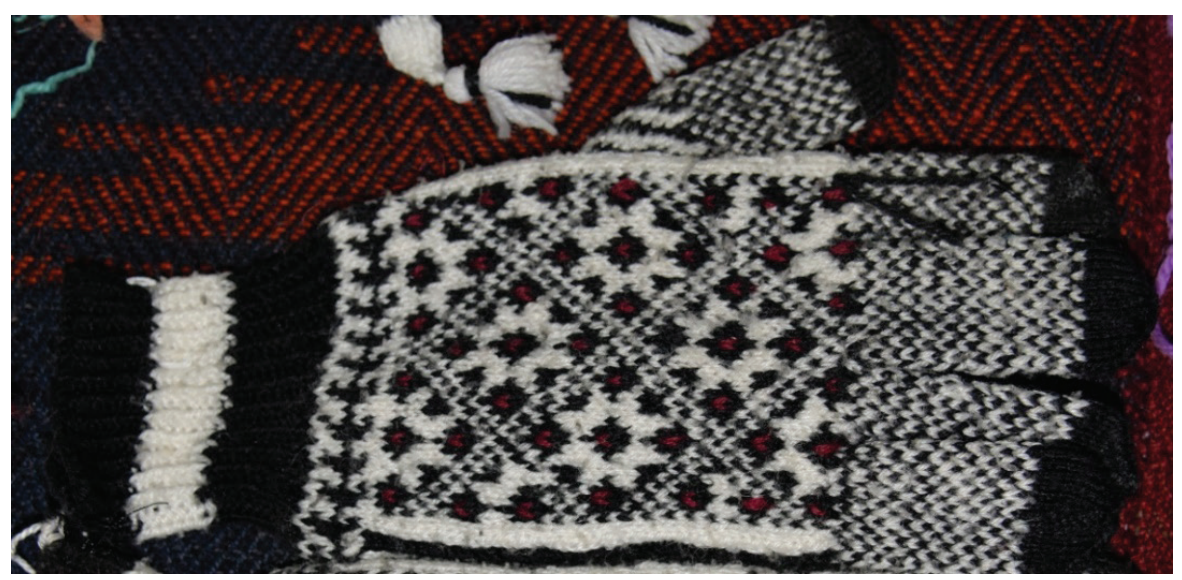

Fotoğraf 9. Örgü lastikli, yıldız motifli yün eldiven.

Halil İbrahimoğlu ev koleksiyonundan, Hakkâri. 


\section{Örnek No: 10}

Eldiven türü: Çocuk yün eldiveni

Malzeme: Teşi ile elde bükülmüş üçem (üç katlı) yün iplik.

Renk: Beyaz, siyah ve mavi; Kullanılan motif: Su yolu

Tanım: Bilek kısmına lastik örgü tekniği uygulanan beş parmaklı yün eldivene kuşak şeklinde iki adet yılanlı su yolu motifi kullanılmıştır.Eldiven parmak uçlarında aynı renk iplikten püsküller eklenmiştir.

Özellikleri: Beş parmaklı bu yün eldiven iki ucu sivri beş şişle örülmüştür. Elleri soğuktan koruma amaçlı yapılan bu eldivenler bezemesiyle büyük dikkat çekmektedir. Bir eser üzerindeki bezeme zenginliği aynı zamanda karşı tarafa verilen önemi yansıtır.

Kullanılan motifin anlamı: Su yolu motifi, suyun insan yaşamındaki yeri ve bununla ilgili kültürü yansıtır. Kırsal alandaki kızların eve su taşıma vesilesiyle uğradıkları köy çeşmeleri başındaki sohbetleri ve hatıraları onların yaşamında ayrı bir yeri vardır. Su yolundaki bu sohbet ve hatıralar aynı zamanda kültür mirasımız için bir kaynak oluşturur. Su yolu motifi ile ilgili Erbaş (2004: 242) şu hususlara yer verir: Tarihi seyir içerisinde insanoğlu suyun hayat verici gücünden hareket ederek ona kutsiyet atfetmiştir. $\mathrm{Bu}$ anlayış, ilahi kaynaklı olmayan dinlere inanan kimi toplumlarda suyun tanrılaştırılmasına kadar varmış, kimilerinde ise dini temizlik vasıtası olarak kullanılmıştır. Kimi toplumlarda sulardan şifa beklentisi kendini gösterirken, kimilerinde gücün ve kuvvetin sembolü kabul edilmiştir.

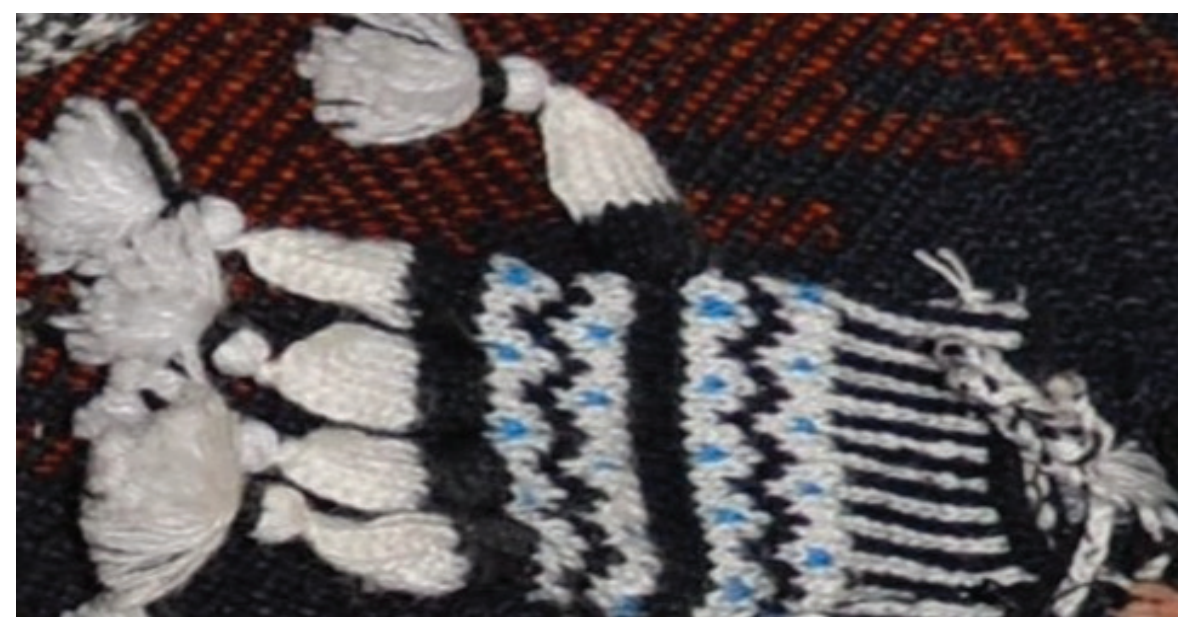

Fotoğraf 10. Hakkâri yöresi su-yolu motifli, parmak uçları püsküllü yün eldiven. Halil İbrahimoğlu ev koleksiyonundan. 


\section{Örnek No: 11}

Eldiven türü: Kışl1k iş yün eldiveni

Malzeme: Teşi ile elde bükülmüş iki katlı yün iplik; Renk: Gri

Kullanılan motif: Üzerinde herhangi bir süslemeye yer verilmemiştir.

Tanım: Tek parmaklı yün eldivendir. Malzeme olarak iki katlı iplikle örülürken eldivende herhangi bir bezemeye yer verilmemiştir. Fotoğrafta görüldüğü üzere, iş eldivenleri malzeme ve işçilik bakımından iyi özelliklere sahip değildirler.

Özellikleri: Hakkâri yöresi yün iplikle örülen iş eldivenleri tek parmaklı veya üç parmaklı olmalarıyla dikkat çeker.Bu tür eldivenlerin örgüsünde iki tarafı sivri beş şiş kullanılır ve bilek kısmında örgü lastik tekniği uygulanır. Böylece çalışırken eldivenin elden kaymasının önüne geçilir. Bilindiği gibi Hakkâri kırsal alanlarında koyun yetiştiriciliği önemli bir uğraştır. Kışın koyunlar ot yığınlarından (loda geya) getirilen otlarla beslenir. Otların taşınmasında bir çeşit kızak kullanılırken, ot bağlarının yüklenmesinde ve indirilme işinde "çatal" denilen bir ahşap alet kullanılır. Bu işi yaparken de elleri hem soğuktan koruma ve hem de kuru otların ve içindeki dikenlerden onları koruma amaçlı kalın yün eldiven giyilir. Tek parmaklı ve üç parmaklı eldivenlerin kullanımının nedenleri arasında birden fazla parmağın bir arada tutulmasıyla ellerin üşümesinin önüne geçilmesidir. Diğer yandan bir nesne kaldırılırken parmaklar üzerindeki denge bu şekilde daha iyi sağlanır. İşte kullanılan yün eldivenler kış mevsiminin sonuna doğru işlevlerini kaybedebilirler. Bazen yeni eldiven örmek yerine yıpranan kısım aynı renkteki yün iplikle bir çuvaldızla onarılır.

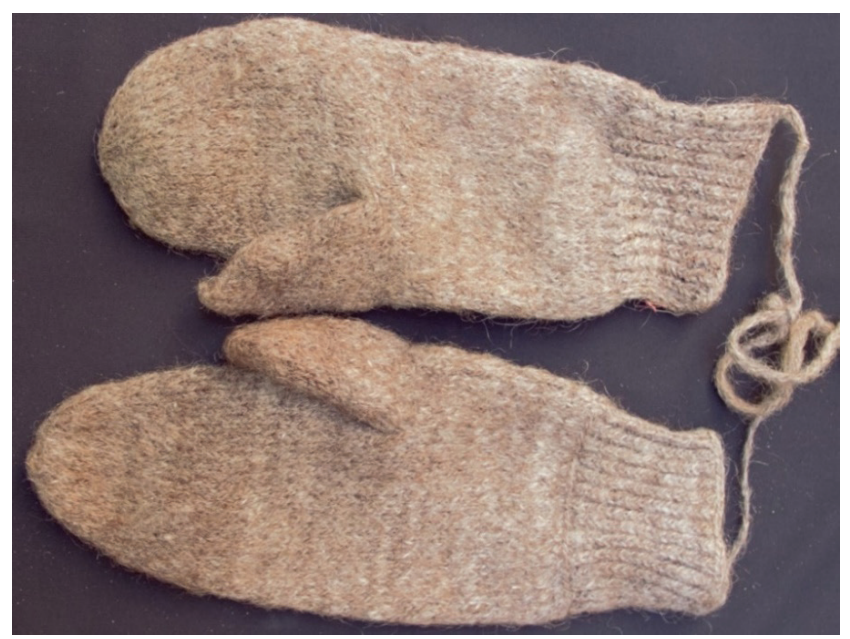

Fotoğraf 11. Karataş köyü, Yüksekova. Bir çift yünlü iş eldiveni 


\section{Örnek No: 12}

Eldiven türü: Süs eldiven

Malzeme: Elde bükülmüş üçem (üç katlı) yün iplik.

Renk: Beyaz, siyah, kırmızı, mavi, yeşil

\section{Fotoğraf: 12}

\section{Kullanılan motif: Muska}

Tanım: Hakkâri yöresi yün eldiven ve çoraplar diğer elbiseleri tamamlayan giyim eşyaları arasındadırlar ve biçimsel özellikleriyle, bezemeleriyle ve kullanılan malzemesiyle diğer giysilerle bir uyum sağlarlar. Hakkâri yöresinde bilhassa genç yaş ve çocuklar için örülen çorap ve eldivenler bezemeleriyle büyük dikkat çekerler. Bu yaştakiler için yapılan yün eldivenler genellikle bilek kısmı örgü lastikli, tamamı desenli, motifli ve parmak uçlarında aynı iplikten veya farklı iplikten yapılmış püsküller görülür. Süs olarak yapılan yün eldivenler bakıldığında genellikle genç yaştaki kişiler için yapılan seyahat eldivenlerinin özelliklerini taşıdıkları görülür. Özellikleri: Bu tür süs yün eldivenler kaybolma riski taşıyan bir sanatın ve buna bağlı kültürün yaşatılmasında önemli bir yere sahip olduklarını söylemek mümkündür. Göz alıcı ve estetik görünüşe sahip bu eserler evlerin en dikkat çekebilecek duvarlarında veya günlük yaşamımızda kullandığımız eşyalar üzerinde bir aksesuar olarak yaygın görmekteyiz. Bunun yanı sıra bir turistik eşya olarak da yerini almıştır. Böylece bir yöreye ait sanat ve kültürün tanıtılmasında önemli bir fonksiyona da sahiptirler.

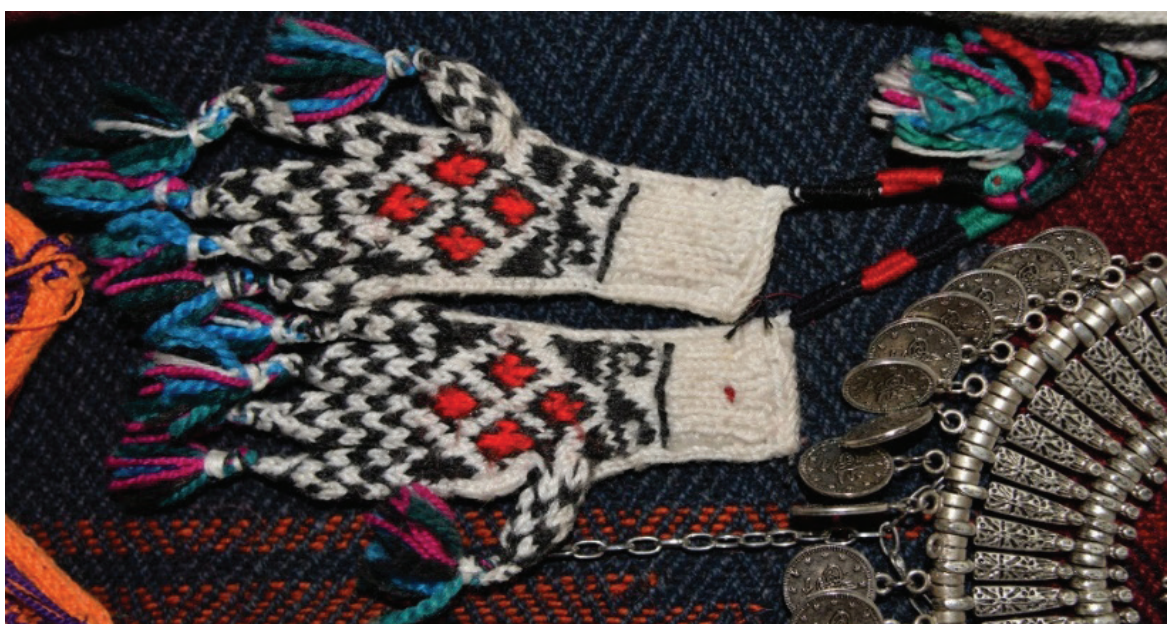

Fotoğraf 12. Nazar (muska) motifli çocuk yün eldiveni. Halil İbrahimoğlu ev koleksiyonundan, Hakkâri. 


\section{Örnek No: 13}

Eldiven türü: Namaz bilekliği

Malzeme: Elde bükülmüş yün iplik.

Renk: Beyaz ve yeşil

Kullanılan motif: Eli belinde

Tanım: Namazlarda kadınlar tarafindan kullanılan yün bilekliklerayağa giyilen "sak" (tozluk) gibi bir görünüme sahiptir (Bkz. Fotoğraf 24). "Sak", yün çorap üzerine giyilir ve üst tarafı daha geniş olur. Böylece içerisine pantolon paçaları rahatlıkla konulabilir. Bilekliklerin iki tarafı da "sak" gibi açık olur ve iki tarafinda da örgü lastik vardır.

Özellikleri: Hakkâri ve yöresinde kışın ayakları soğuktan koruma amaçlı yün çorapların yapıldığı gibi sadece namazlarda kullanılmak üzere örülen kadın ve erkek namaz çorapları da yapılmaktadır.Bunlar namaziçin giyilir ve namazdan sonra çıkarılarak bir sonraki vakit namazda giymek üzere kaldırılır. Namaz çorapları biraz bol olur ve böylece giyilmesi, çıkarılması kolay olur.

Diğer taraftan,kışın elleri soğuktan koruma amaçlı yün eldiven örülür. Namaz çorabı gibi yörede namaz eldivenine rastlanmaz. Ancak namaza duracak kadının elbisesinin kolları bileğe kadar uzun olmaması durumunda kollarındaki örtünmeyen kısmı kapatmak üzere yün iplik malzemeden örülmüş bileklikleri kullanır. Erkeklere ait namaz bilekliği yoktur.

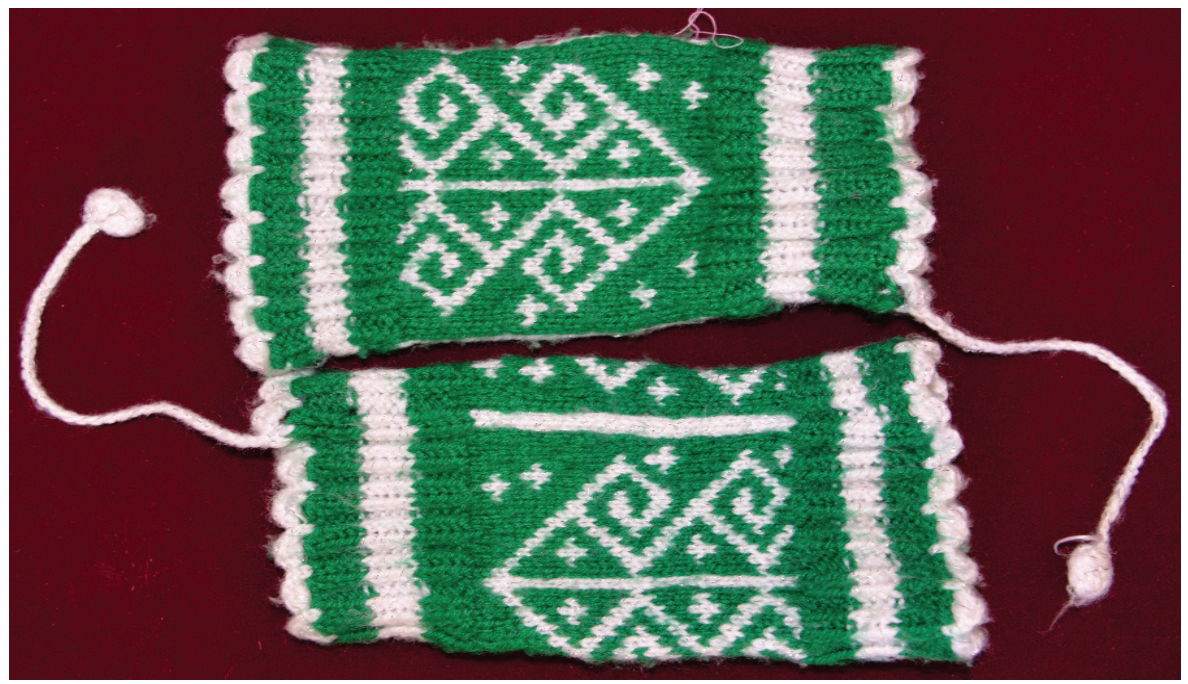

Fotoğraf 13. Eli belinde motifine sahip namaz bilekliği. Çığlı köyü, Çukurca. 


\section{HAKKÂRI YÜN ELDİVENLERIYLE YÜN ÇORAPLARI ARASINDA BİR KARŞILAŞTIRMA}

Hakkâri yöresi dokuma ve örgü işi el sanatları açısından önemli bir yere sahiptir. Dokuma olarakkilim, mêzer (kıl çadırlarda ara perde veya yatak örtüsü, yaygı olarak kullanılır), farklı boylarda ve farklı ölçülerde heybeler, parzun (sırtta yük taşımaya yarar) ve çuval gibi unsurlar görülürken örgü olarak da yün çoraplar ve yün eldivenler ön plana çıkar. Sıralanan bu el sanatları unsurlarının yapımı oldukça uzun zaman alır ve büyük bir emekle, göz nuruyla ortaya çıkarlar. Bir kadın birden çok el sanatı türünde yetenekli olabilir. Örneğin, kilim dokumada iyi olabileceği gibi çok güzel çorap da örebilir. Bu ve buna benzer nedenlerden dolayı dokumada görülen motiflerin birçoğunu örgü sanatında da görebilmekteyiz (Fotoğraf 14).

Hakkâri kilimleri üzerinde birçok farklı motif vardır ve her birinin farklı anlamı vardır. Ancak her bir kilim üzerindeki motiflerkompozisyonu bir hikâyeyi oluşturur. Bu da o eseri ortaya koyan sanatçının hikâyesidir. Bunun için de kilimler bezeme açısından ele alındığında dokumacının hikâyesiyle bütünleştirilir. Diğer taraftan yün çorap ve yün eldivenler üzerindeki motif sayısı az olduğundan (bir veya birden fazla olabiliyor) bir hikâyeyi oluşturmazlar. Bunun yerine birer mesaj niteliğindedirler: Buğrul: (2018: 52);

"Hakkâri yöresinde evlenme çağında olan kişi birisiyle evlenme niyetinde olduğu zaman ona genellikle ayna ve tarak gönderir. Bu açıklamalar göz önünde bulundurulduğunda birisine tarak motifli çorabın hediye edilmesi, öznenin nesneyi hediye ettiği kişi ile evlenme arzusunda olduğu anlamı yüklenir".

Yün eldivenler; malzeme, bezeme ve bezemelerin taşıdığ1 anlam, örgü tekniği ve yapılış amaçları bakımından yün çoraplarla büyük bir benzerlik gösterirler. $\mathrm{Bu}$ anlamda bu kültür ve sanat eserlerini karşılaştıracak olursak:

\section{Benzer özellik olarak:}

- Aynı malzeme ile örülmektedirler. İki ucu sivri beş şiş, iki katlı veya üçem yün iplik ve/veya keçi kılları arasında yün vari tabakadan (kaşmir) elde edilen iplik görülür.

- Keçi kılları arasındaki yün vari tabakadan elde edilen iplik yumuşaklığı ile dikkat çeker. Bunun için de bundan örülen eldiven ve çoraplar "tiftik eldiven" ve "tiftik çorap" olarak adlandırılır.

- Tamamı renkli ve desenli, örgü desenli ve motifli ve/veya sade örgü desenlidirler. 
- Lastik örgü tekniği uygulanmaktadır.

- Kışın soğuktan korunma amaçlı örülmektedirler.

- Özel gün veya seyahat amaçlı örülen yün çorap / yün eldivenler bezeme, malzeme ve ince işçilik bakımından çok önemli bir yere sahiptirler.

- Bir işte kullanılmak üzere örülen yün çorap / yün eldivenlerde kalite düşüktür.

- Yün eldivenler ve yün çoraplar benzer bezemeye sahiptirler. Hakkâri yün çoraplarında görülen motiflerden önemli bir kısmını yün eldivenler üzerinde de görebilmekteyiz. Dolasıyla üzerlerine işlenen motifler benzer mesajları içerirler.

Bu motiflerden bazılarını iki sanat unsuru üzerinde de görecek olursak:

Tablo 1: Yün Eldiven ve Yün Çorap Motiflerinde Bir Karşılaştırma

\begin{tabular}{|l|l|l|l|}
\hline \multirow{2}{*}{ S/N } & \multirow{2}{*}{ Motif adı / Çorap türü } & \multicolumn{2}{|c|}{ Fotoğraf No } \\
\cline { 3 - 4 } & & Yün Eldiven & Yün Çorap \\
\hline 1 & Göz motifi & 2 & 15 \\
\hline 2 & Eli belinde motifi & 3 & 16 \\
\hline 3 & Koçbaşı motifi & 4 & 17 \\
\hline 4 & Hayat ağac1 & 5 & 18 \\
\hline 5 & Baklava desen & 6 & 19 \\
\hline 6 & Nazar motifi & 7 & 20 \\
\hline 7 & Pitrak motifi & 8 & 21 \\
\hline 8 & Yıldız motifi & 9 & 22 \\
\hline 9 & Suyolu motifi & 10 & 23 \\
\hline 10 & Süs eldiven ve çorap & 12 & $24-25$ \\
\hline 11 & Püsküllü eldiven ve tozluk & $3-5-7-8-10-12$ & 26 \\
\hline
\end{tabular}

\section{İki unsur arasındaki farklı özelliklere bakıldığında:}

- Yün çoraplar daha kısa ömürlüdür. Bir kişi bir yılda iki-üç çift yün çorap yıpratırken, bir çift yün iş eldiveni bir yıl kadar dayanabilir. Sadece seyahat esnasında kullanılan eldivenler ise bir ömür boyu kullanılabilir.

- Sık kullanıldığg takdirde sadece birkaç ay ömrü olan yün çoraplara yeniden ihtiyaç duyulduğu için yün çorap örgüsü eldiven örgüsü ile kıyaslanmayacak kadar yaygindır.

- Eldiven parmak uçlarında, bilhassa genç yaştaki kişiler için yapılanlarda, aynı veya farklı renkten yapılmıs püsküller görülür. Aynı özelliği özel 
günlerde yün çoraplar üzerinde giyilen yün tozlukların bağcıklarında görmekteyiz.

- Yün çoraplarda bağcık yaygın görülürken, yüne eldivenlerde çok az rastlanir.

- Ayakların ve bacakların islanmasına karşın yün çoraplar üzerine giyilen keçi kılından yapılmış tozluklara rastlanırken,keçi kılından yapılmış eldivene rastlanılmamıştır. Ancak Hakkâri yöresinde lastik ayakkabıların temin edilemediği bir dönemde keçi kılından yapılmış ayakkabıların kullanıldığı bilinmektedir.

\section{DEĞERLENDİRME VE SONUÇ}

Yün eldivenler kış mevsiminde ellerimizi soğuktan koruma gibi önemli bir ihtiyacımızı karşıladıkları için bizler için önemli bir giyim eşyası olmalarının yanı sıra uzak geçmişimizin kültürel değerlerini yansıtan bezemeye sahip olmalarıla da ayrı bir anlam ve öneme sahiptirler. Farklı motiflerin kullanıldığ 1 bu kültür ve sanat eserleri genellikle dil veya yazıya dökülemeyen şu mesajları karşı tarafa aktarırlar:

- Kadın aksesuarlarından tarak, bilezik, saç bağı, gerdanlık vb. motiflerle karşı tarafa olan duygusal ilişki, evlenme arzusunu,

- Yıldız, koçbaşı ve bereket motifleriyle birine duyulan hayranlık ve onun bolluk içerisinde yaşaması temennisini,

- Bukağı ile karşı tarafa olan sadakati,

- Pitrak, göz, el ve muska motifleriyle akrep, yilan, ejder vb. gibi hayvanların stilize figürü ile nazardan ve kötülüklerden korunma temennisi,

- Su yolu motifi ile yaşamın ve suyun yaşamımızdaki önemini,

- El motifi ile Peygamberimize ve ailesine olan sevgiyi.

Benzeri birçok motifi daha burada vermek mümkündür. Yukarıda değinilen motifler arasında nazara karşı etkili olacağı düşünülen bezemeler ön plana çıkar. Geleneksel yöntemlerle ortaya çıkarılan kültür ve sanat değeri olan Hakkâri yöresi yün eldivenlerinin özelliklerini özetleyecek olursak:

- Doğal malzemeden yapılmaktadırlar,

- Sağlik açısından çok önemli bir yere sahiptirler,

- Uzak geçmişten gelen kültür, inanç ve geleneklerimizi yansıtırlar,

- Sanatçının hayal gücünü, duygularını, düşüncelerini, zevklerini ve dünya görüşünü yansitan tezyine sahiptirler, 
- Üzerlerine işlenen motif ve desenler birer tema / mesaj taşırlar ve toplumsal bir algi ifade ederler,

- Estetik görünümleriyle büyük bir dikkat çekerler,

- Anadolu'nun diğer yöreleriyle benzer özellikleri yanında Hakkâri yöresine has özellikler taşırlar. Bu bakımdan birer marka değerindedirler.

Sonuç olarak: Sanat ve kültürel değerlerimiz içerisinde önemli bir yere sahip olan yün eldivenler, malzeme olarak fazla dayanıklı olmamasından, günümüzde onların yerine farklı malzemeden yapılmış eldivenlerin tercih edilmesinden ve buna benzer diğer nedenlerden dolayı bütünüyle kaybolma riskini taşımaktadırlar. Yapılan araştırmada son birkaç yıl içerisinde örülmüş yün eldivene rastlanmadığ 1 gibi geçmişte yapılmış yün eldivenlerin yeterince korunmadığ1 görülmüştür. Geçmiş yıllarda Hakkâri ve yöresinde her şahsın farklı amaçlarla kullandığı iki-üç veya daha fazla yün eldiveni vardı. Yapılan saha çalışmasında 30 civarındaki yerleşim yerinde sadece 20 kadar çift eldivene rastlanılması bu sanatın bugünkü durumunu açıkça ortaya koymaktadır. Birkaç yıl sonra bu durumun yün çoraplar ve dokuma işlerinde de görülebileceği endişesi taşınmaktadır. Temennimiz, bu sanatın içinde bulunduğu riskten kurtarılması ve gelecek nesillere aktarılmasıdır. Burada birkaç öneride bulunacak olursak:

- Yaşam müzelerinin kurulması ve buralarda etnografik eserlerin teşhiri yanında dokuma, örgü ve daha farklı el sanatlarının üretiminin sağlanmasi,

- Projeler vasıtasıyla farklı ürünlerin elde edilmesine gidilmesi. Geçmişte önemli işlevi olan çuval, heybe, parzun gibi ürünler yerine günümüz yaşamın ihtiyaçlarını karşılayan ürünlerin elde edilmesi,

- Ürünlerin özellikleri, işlevleri, yararları yanında bunların üzerlerinde yer alan motif ve desenlerin taşıdığı anlamları ortaya koyan bilimsel çalışmalara daha fazla gidilmesi,

- Bu sanatların canlanması için farklı kursların düzenlenmesi önemli bir katkıdır. Ancak bunda pek fazla yol alındığı söylenemez. Bunların yeniden gözden geçirilmesi,

- Yün ipliğin elde edilmesinde büyük bir sıkıntı yaşanmaktadır. İran'dan getirtmek yerine, renkli iplik olmak üzere, farklı özelliklere sahip yün ipliğin elde edilmesi için altyapının oluşturulmasında ve bu malzemenin üreticilere ulaşmasında devlet katkısının sağlanması önem taşıyacaktır. 


\section{Kaynaklar}

Akpınarlı, H. Feriha ve H. Ayşegül Özdemir, (2016). "Konya - Ladik Halılarındaki Motiflerin İncelenmesi”, DOI: 10,7816/idil-05-23-11Idil, Issue 23. s. 964.

Al-Zadjali, Zahra(2015). "Investigation of the Metaphysical Symbolism of Omani Rug Designs", Global Journal on Humanities \& Social Sciences, Academic World Education \& Research Center, s.404-408.

Alpenfels, Ethel J. (1955). "The Anthropology and Social Significance of the Human Hand”, Digital Resource Foundation, Vol 2, Num 2. 4-21.

Atay, Ayten (1987). Örücülük, Milli Eğitim Basımevi, İstanbul.

Bozkurt, Nejat (1995). Sanat ve Estetik Kuramları, 2.bsk. Sarmal Yayınevi. İstanbul.

Buğrul, Hasan (2018). Sanat ve Kültürel Değer Olarak Hakkari Yün Çorapları / As an Art and CulturalAsset - Hakkari WoolenSocks, Bilgin Kültür Sanat Yay.,Ankara.

Busatta, Sandra (1973). "The Tree of Life Design from Central Asia to Navajoland and Back", Antrocom Online Journal of Anthropology, vol. 9. N. 1: s. 216.

Çoruhlu, Yaşar (2012). Türk Mitolojisinin Ana Hatları, Kabalcı Yayınevi.

Erbek, Güran (1987). Anatolian Motifs from Çatalhöyük to the Present, 3. Baski.

Okca, Ayşegül K. (2015). “Geleneksel Anadolu Halı ve Kilimlerinde Nazar İnancı: Muska Yanışı”, Turkish Studies InternationalPeriodical For The Languages, Literature and History of Turkish or TurkicVolume 10/8 Spring, s.1667-8.

Kamenova, Dora (2011). Pastoral Life in Art, Research Theme 9: Bulgaria.

Nişanc1, Z. Nuray (2012). “Toplumsak Kültür - Örgüt Kültürü İlişkisi ve Yönetim Üzerine Yansımaları”, Batman University, Journal of Life Sciences, Volume I, p.1282.

Özen, Onur (2016). Yerli Üretim iş Eldivenlerinin Ürün Güvenliğinin Değerlendirilmesi, T.C. Çalışma ve Sosyal Güvenlik Bakanlığg İş Sağlığ1 ve Güvenlik Genel Müdürlüğü, İş Sağlığ1 ve Güvenliği Uzmanlık Tezi, Ankara. 
Sarıtaş, Süheyla (2007). "Maddi Kültür ve El Sanatlarına Yansımaları", 38. ICANAS Uluslararası Asya ve Kuzey Afrika Çalışmaları Kongresi, Ankara, s. 1121.

Taşkıran, M. Nurdan (2016). "Reading Motifs on Kilims", A Semiotic Approach to Symbolic Meaning, University of Kocaeli, İstanbul, s. 14.

Ekler:

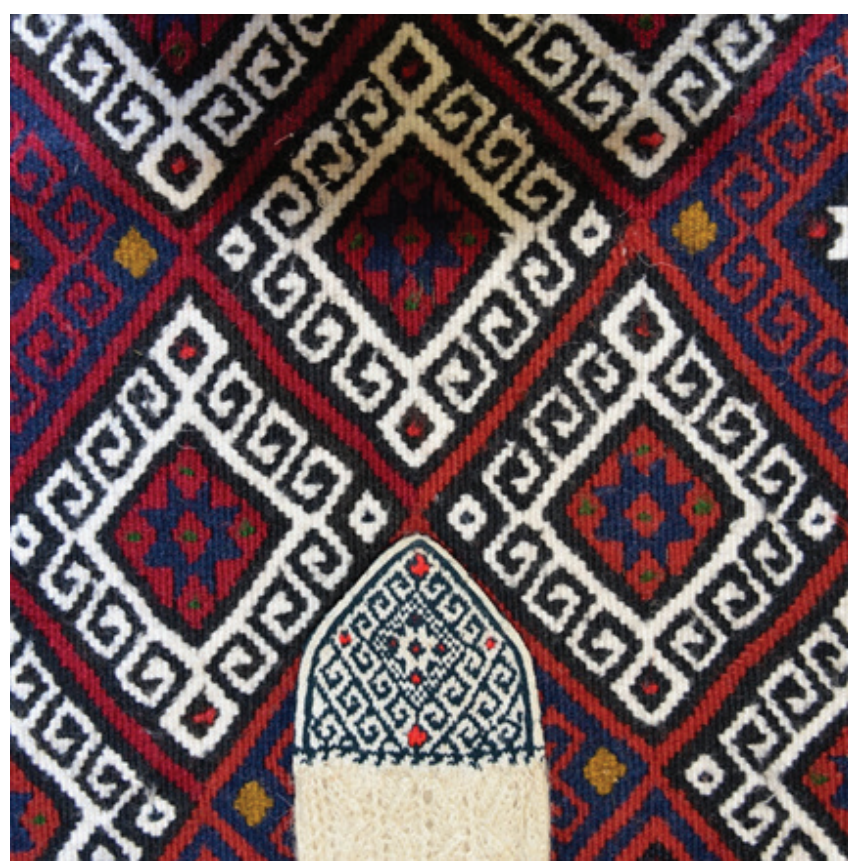

Fotoğraf 14. Kilim deseninden yararlanılarak örülmüş bir yünlü çorap. Geçitli beldesi, Hakkâri.

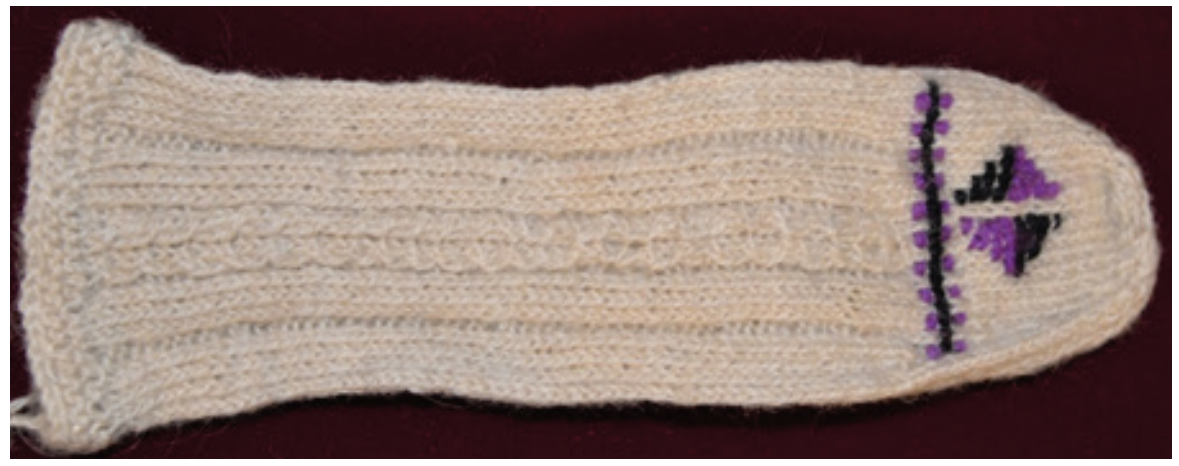

Fotoğraf 15. Hakkâri yöresi göz motifli yün çorap. 


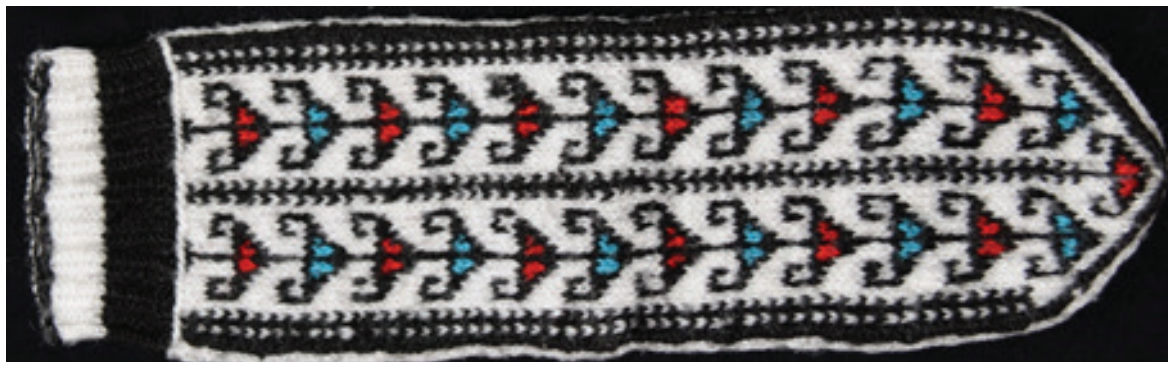

Fotoğraf 16. Hakkâri yöresi eli belinde motifli yün çorap.

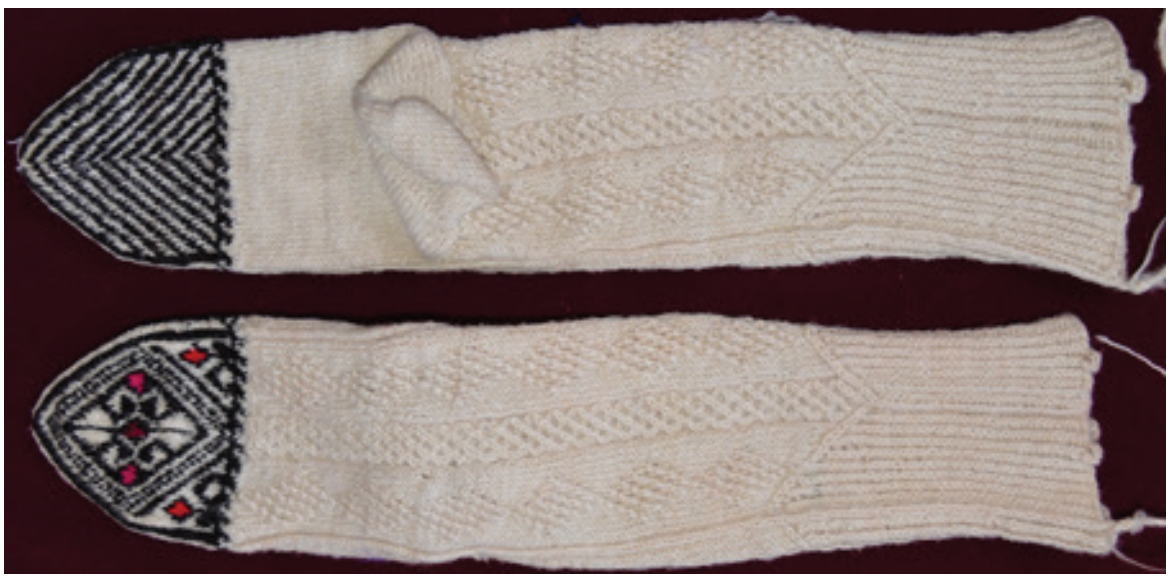

Fotoğraf 17. Hakkari yöresi koçbaşı motifli yün çorap.

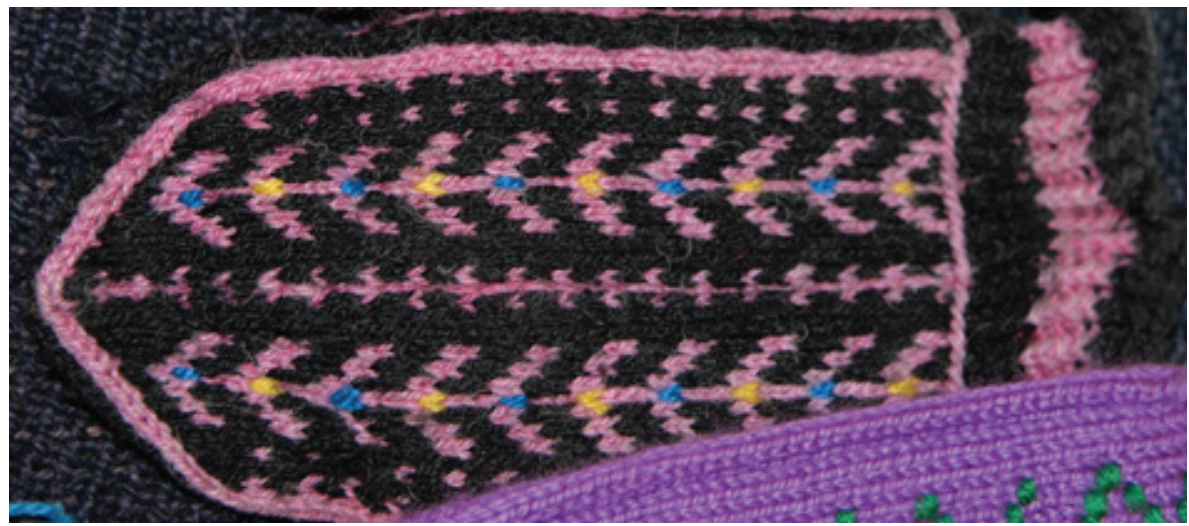

Fotoğraf 18. Hakkâri yöresi hayat ağacı motifli yün çorap. 


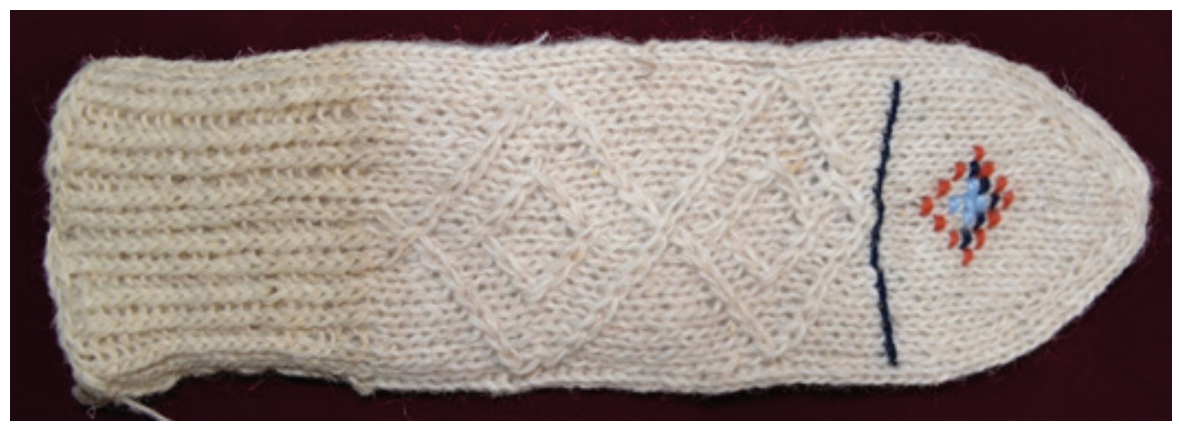

Fotoğraf 19. Hakkâri yöresi baklava desenli yün çorap.

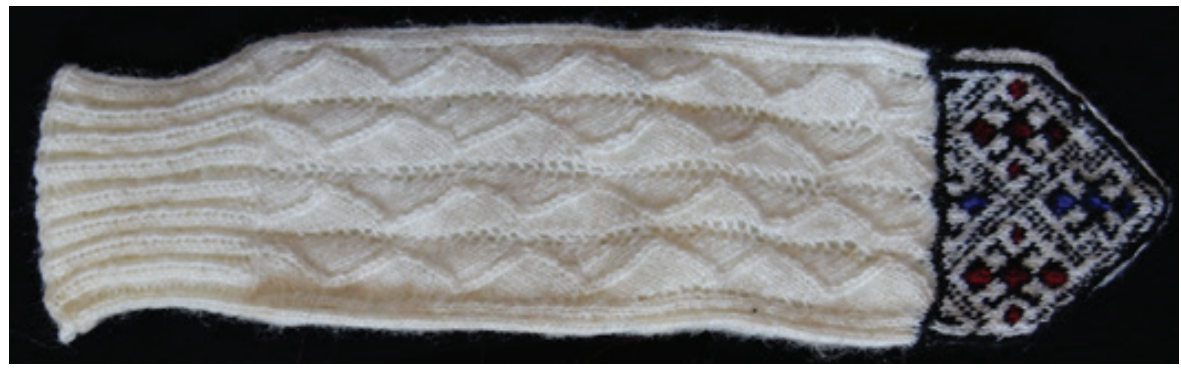

Fotoğraf 20. Hakkâri yöresi nazar motifli yün çorap.

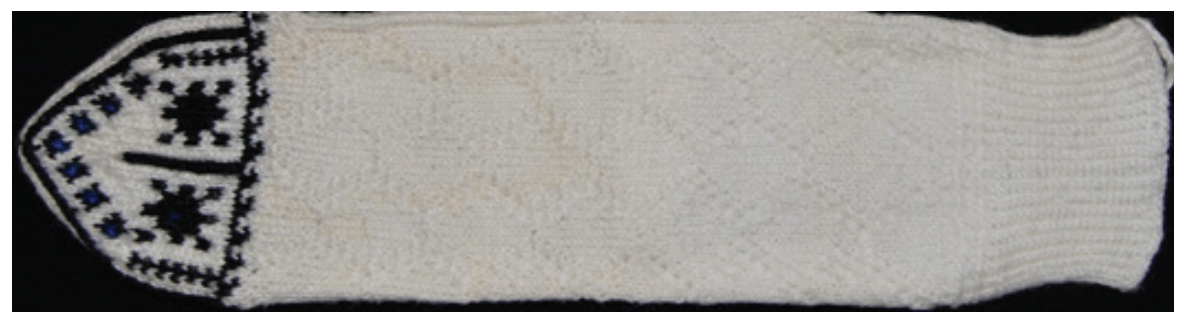

Fotoğraf 21. Hakkâri yöresi pitrak motifli yün çorap.

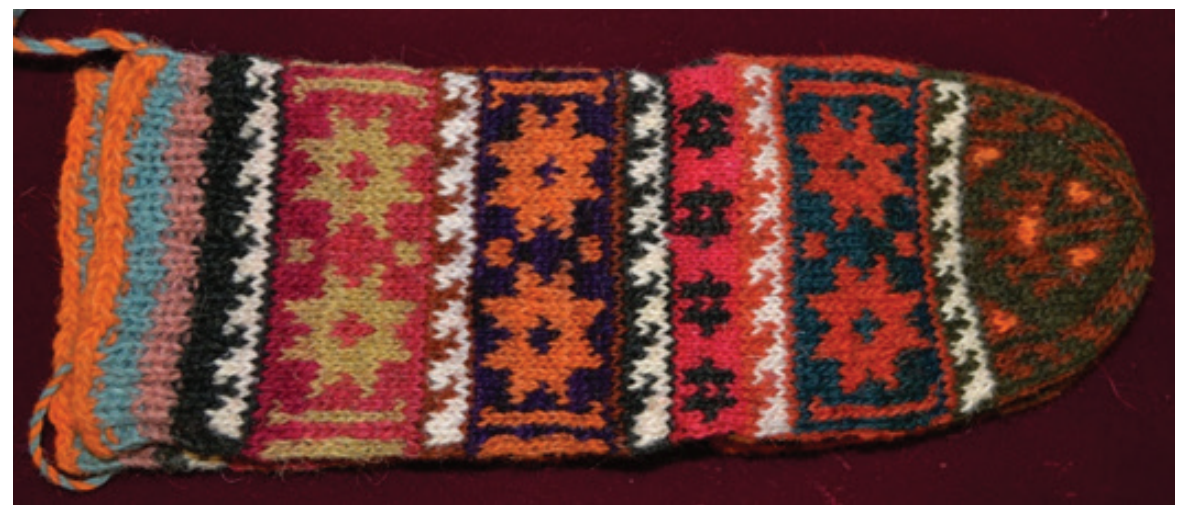

Fotoğraf 22. Hakkâri yöresi yıldız motifli yün çorap. 


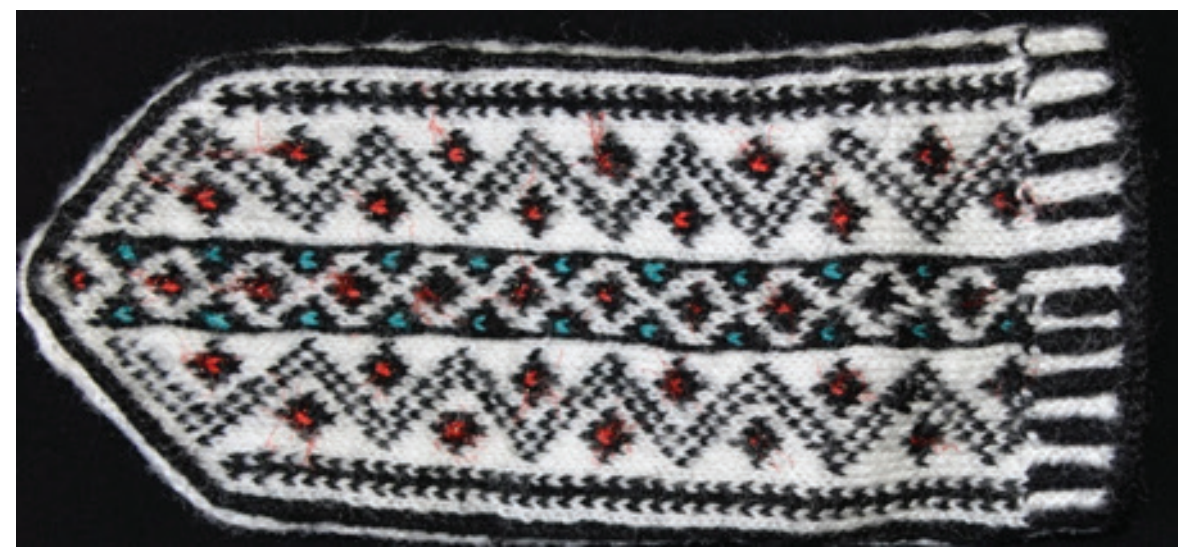

Fotoğraf 23. Hakkâri yöresi su yolu motifli yün çorap.

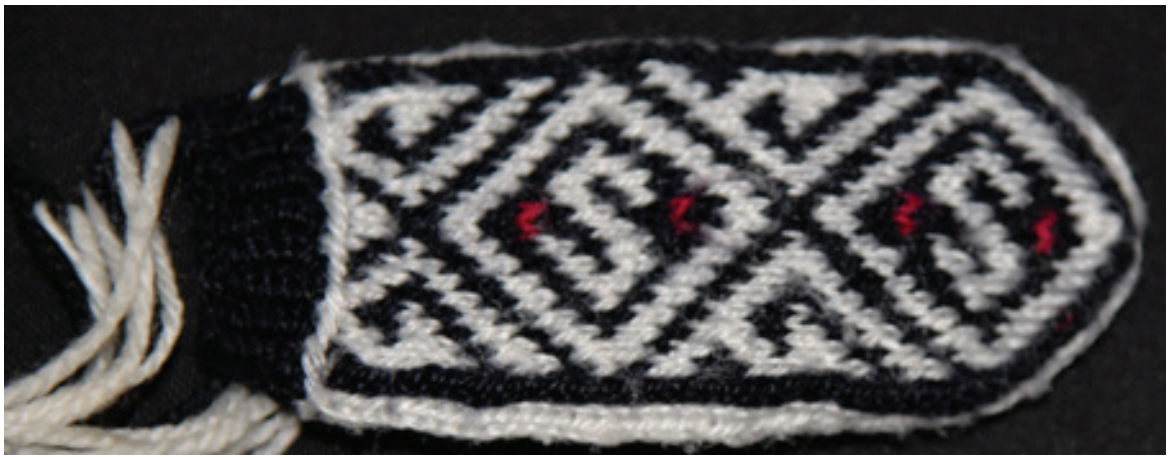

Fotoğraf 24. Hakkâri yöresi maskot (süs) çorap.

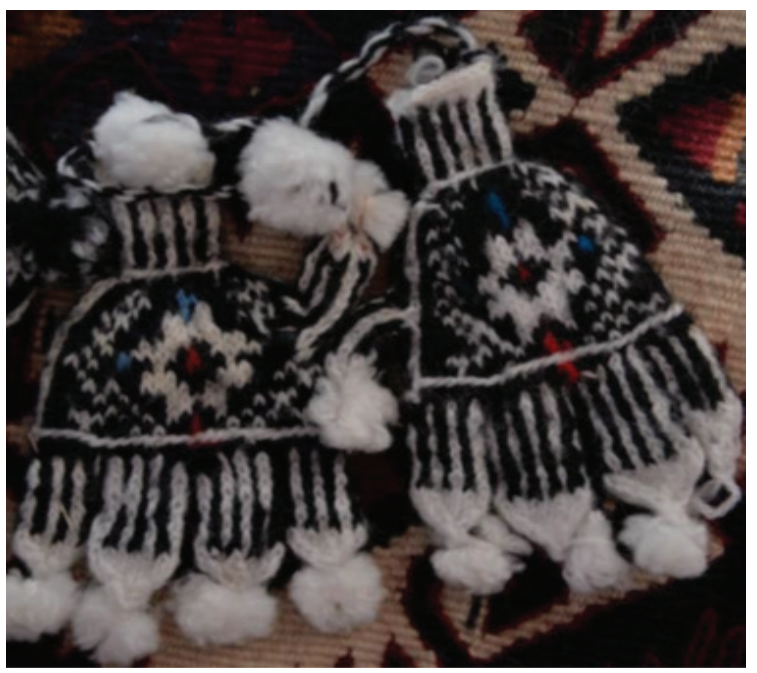

Fotoğraf 25. Hakkâri yöresi yıldız motifli süs eldiven örneklerinden biri. 


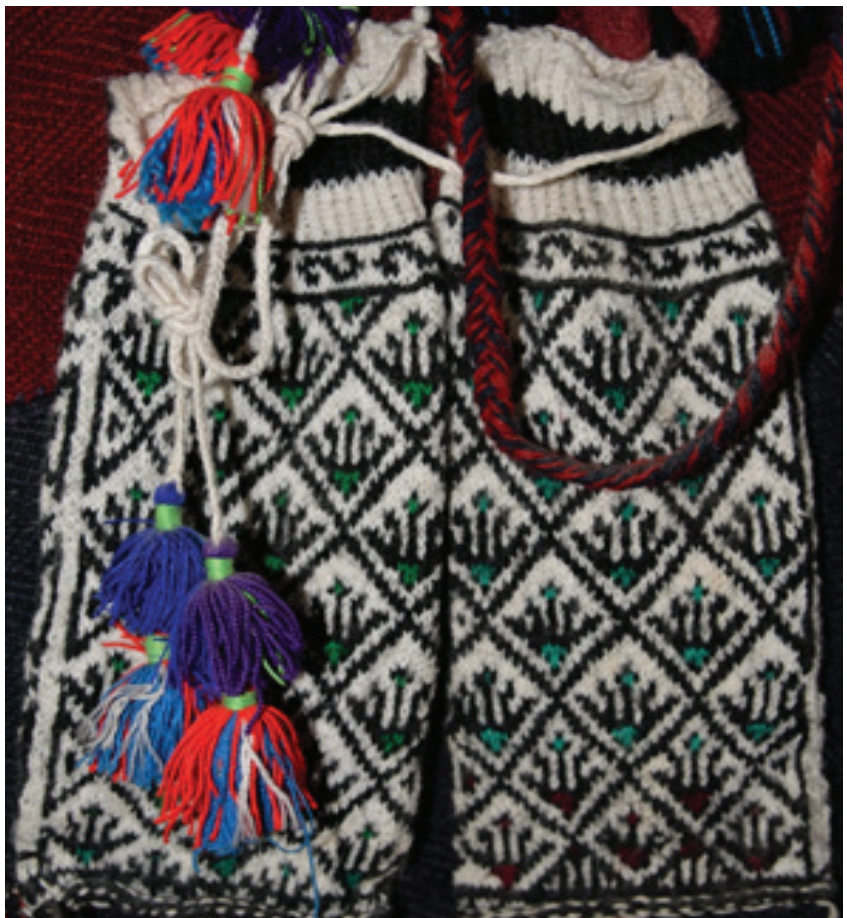

Fotoğraf 26. Hakkâri yöresi özel günlerde yün çoraplar üzerine giyilen ve pantolon paçalarının de içine konulduğu tozluk. Tozlukların üst kısmının inmemesi için püsküllü bağcıklarla bağlanır. 
